\title{
What Do We Have to Know about PD-L1 Expression in Prostate Cancer? A Systematic Literature Review. Part 3: PD-L1, Intracellular Signaling Pathways and Tumor Microenvironment
}

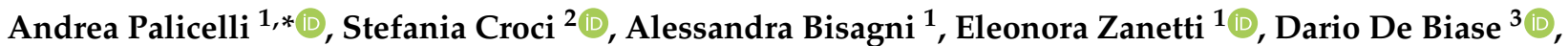 \\ Beatrice Melli ${ }^{4,5}{ }^{1}$, Francesca Sanguedolce ${ }^{6}$, Moira Ragazzi ${ }^{1}$, Magda Zanelli ${ }^{1}{ }^{\circledR}$, Alcides Chaux ${ }^{7}$, \\ Sofia Cañete-Portillo ${ }^{8}$, Maria Paola Bonasoni ${ }^{1}$ (D), Alessandra Soriano ${ }^{9,10}$, Stefano Ascani ${ }^{11,12}$, \\ Maurizio Zizzo ${ }^{13}{ }^{\circledR}$, Carolina Castro Ruiz ${ }^{5,13}$, Antonio De Leo ${ }^{14}{ }^{\mathbb{D}}$, Guido Giordano ${ }^{15}$, \\ Matteo Landriscina ${ }^{15}{ }^{\circledR}$, Giuseppe Carrieri ${ }^{16}$, Luigi Cormio ${ }^{16}$, Daniel M. Berney ${ }^{17}$, Jatin Gandhi ${ }^{18}$, \\ Valerio Copelli ${ }^{1}$, Giuditta Bernardelli ${ }^{1}$, Giacomo Santandrea ${ }^{1,5}(\mathbb{D})$ and Martina Bonacini ${ }^{2}(\mathbb{D}$
}

check for updates

Citation: Palicelli, A.; Croci, S. Bisagni, A.; Zanetti, E.; De Biase, D.; Melli, B.; Sanguedolce, F.; Ragazzi, M.; Zanelli, M.; Chaux, A.; et al. What Do We Have to Know about PD-L1

Expression in Prostate Cancer? A Systematic Literature Review. Part 3: PD-L1, Intracellular Signaling Pathways and Tumor Microenvironment. Int. J. Mol. Sci. 2021, 22, 12330 .

https://doi.org/10.3390/ ijms222212330

Academic Editor: Gabriella Castoria

Received: 12 August 2021

Accepted: 27 October 2021

Published: 15 November 2021

Publisher's Note: MDPI stays neutral with regard to jurisdictional claims in published maps and institutional affiliations.

Copyright: (c) 2021 by the authors Licensee MDPI, Basel, Switzerland. This article is an open access article distributed under the terms and conditions of the Creative Commons Attribution (CC BY) license (https:// creativecommons.org/licenses/by/ $4.0 /)$
1 Pathology Unit, Azienda USL-IRCCS di Reggio Emilia, 42123 Reggio Emilia, Italy; Alessandra.Bisagni@ausl.re.it (A.B.); Eleonora.Zanetti@ausl.re.it (E.Z.); Moira.Ragazzi@ausl.re.it (M.R.); Magda.Zanelli@ausl.re.it (M.Z.); mariapaola.bonasoni@ausl.re.it (M.P.B.); valerio.copelli@ausl.re.it (V.C.); giuditta.bernardelli@ausl.re.it (G.B.); giacomo.santandrea@ausl.re.it (G.S.)

2 Clinical Immunology, Allergy and Advanced Biotechnologies Unit, Azienda USL-IRCCS di Reggio Emilia, 42123 Reggio Emilia, Italy; Stefania.Croci@ausl.re.it (S.C.); Martina.Bonacini@ausl.re.it (M.B.)

3 Department of Pharmacy and Biotechnology (FABIT), University of Bologna, 40126 Bologna, Italy; dario.debiase@unibo.it

4 Fertility Centre, Department of Obstetrics and Gynecology, Azienda USL-IRCCS di Reggio Emilia, 42123 Reggio Emilia, Italy; Beatrice.Melli@ausl.re.it

5 Clinical and Experimental Medicine PhD Program, University of Modena and Reggio Emilia, 41121 Modena, Italy; Carolina.CastroRuiz@ausl.re.it

6 Pathology Unit, Policlinico Riuniti, University of Foggia, 71122 Foggia, Italy; francesca.sanguedolce@unifg.it

Department of Scientific Research, School of Postgraduate Studies, Norte University, Asunción 1614, Paraguay; alcideschaux@uninorte.edu.py

8 Department of Pathology, University of Alabama at Birmingham, Birmingham, AL 35294, USA; scaneteportillo@uabmc.edu

9 Department of Pathology, Case Western Reserve University, Cleveland, OH 44106, USA; alessandra.soriano@ausl.re.it

10 Gastroenterology Division, Azienda USL-IRCCS di Reggio Emilia, 42123 Reggio Emilia, Italy

11 Pathology Unit, Azienda Ospedaliera Santa Maria di Terni, University of Perugia, 05100 Terni, Italy; s.ascani@aospterni.it

12 Haematopathology Unit, CREO, Azienda Ospedaliera di Perugia, University of Perugia, 06129 Perugia, Italy

13 Surgical Oncology Unit, Azienda USL-IRCCS di Reggio Emilia, 42123 Reggio Emilia, Italy; Maurizio.Zizzo@ausl.re.it

14 Molecular Diagnostic Unit, Azienda USL Bologna, Department of Experimental, Diagnostic and Specialty Medicine, University of Bologna, 40138 Bologna, Italy; antonio.deleo@unibo.it

15 Medical Oncology Unit, Department of Medical and Surgical Sciences, University of Foggia, 71122 Foggia, Italy; guido.giordano@unifg.it (G.G.); matteo.landriscina@unifg.it (M.L.)

16 Department of Urology and Renal Transplantation, University of Foggia, 71122 Foggia, Italy; giuseppe.carrieri@unifg.it (G.C.); luigi.cormio@unifg.it (L.C.)

17 Barts Cancer Institute, Queen Mary University of London, London EC1M 5PZ, UK; daniel.berney@nhs.net

18 Department of Pathology and Laboratory Medicine, University of Washington, Seattle, WA 98195, USA; jgandhi@uw.edu

* Correspondence: Andrea.Palicelli@ausl.re.it; Tel.: +39-0522296864; Fax: +39-0522296945 
cells (regulatory T, M2 macrophagic, myeloid-derived suppressor, dendritic, stromal, and adipocytic cells). IFN- $\gamma$ (the most investigated factor), TGF- $\beta$, TNF- $\alpha$, IL-6, IL-17, IL-15, IL-27, complement factor $\mathrm{C} 5 \mathrm{a}$, and other soluble molecules secreted by TME components (and sometimes increased in patients' serum), as well as and hypoxia, influenced the regulation of PD-L1. Experimental studies using human and mouse PC cell lines (derived from either androgen-sensitive or androgenresistant tumors) revealed that the intracellular ERK/MEK, Akt-mTOR, NF-kB, WNT and JAK/STAT pathways were involved in PD-L1 upregulation in PC. Blocking the PD-1/PD-L1 signaling by using immunotherapy drugs can prevent tumor immune-escape, increasing the anti-tumor activity of immune cells.

Keywords: PD-L1; prostate; cancer; signaling pathways; tumor microenvironment; target-therapy; immunotherapy; checkpoint inhibitors

\section{Introduction}

The tumor microenvironment (TME) includes immune cells, stromal/mesenchymal cells (such as activated fibroblasts or adipocytes), blood vessels, extracellular matrix, as well as cytokines, chemokines, and other soluble factors released by each TME-component. The interactions between these different TME elements influence tumor growth and cancer survival/progression, enabling tumor cell immune-evasion. TME influences the immunogenicity of various tumor types, including prostate cancer (PC) [1-3]. Programmed death-1 (PD-1) is a type I transmembrane glycoprotein of the CD28/CTLA-4 family, encoded by $P D C D 1$ gene (located on chromosome 2). Its expression is inducible upon cell activation, and strictly related to hematopoietic cells (activated T, B, NK cells and monocytes) [2,3]. The PD-1 protein consists of an extracellular IgV-type domain, a transmembrane region and an intracellular tail characterized by immunoreceptor tyrosine-based inhibitory and switch motifs responsible for the intracellular signaling cascade [1-3].

In humans, two PD-1 ligands have been identified: PD-L1 and PD-L2 [2,3]. They are type I transmembrane glycoprotein B7 family members transcribed by CD274 and PDCD1LG2 genes, respectively: both genes are located on chromosome 9. Their expression in hematopoietic and non-hematopoietic cells is inducible by microenvironmental conditions; PD-L1 shows a higher and more widespread expression profile than PD-L2, which is more frequently expressed on antigen-presenting cells (dendritic cells and macrophages) [2,3]. PD-L1 and PD-L2 proteins consist of IgC and IgV-type extracellular domains, a transmembrane region and an intracellular tail without any canonical signaling motifs $[2,3]$.

The PD-1/PD-L1 signaling pathway is involved in the regulation of the tumor immune escape by its effects on inflammatory cells ( $\mathrm{T}$ and B lymphocytes, NK cells, macrophages, dendritic cells) and other TME components. It inhibits the tumor-infiltrating lymphocytes (TILs) and NK cells function/activation, favoring TILs apoptosis, and influencing the T helper and myeloid cell differentiation; moreover, the secretion of immunosuppressive cytokines is promoted, decreasing the production of effector cytokines [1-4]. The identification of novel prognostic markers strictly linked to the development of targeted therapies is urgently required in various tumors, including PC [4-7]. Blocking PD-L1 using checkpoint inhibitors may restore the anti-tumor activity of immune cells $[2,3,8,9]$.

To delineate the intracellular signaling pathways and the extracellular TME factors involved in PD-L1 expression, we have performed a systematic literature review of human tissue-based studies (immunohistochemical, molecular, etc.), experimental research (cell lines, mouse models), and closed clinical trials. 


\section{Results}

\subsection{Literature Review Results}

Figure 1 presents the "Preferred Reporting Items for Systematic Reviews and MetaAnalyses" (PRISMA) (http:/ / www.prisma-statement.org/ accessed on 8 May 2021) flow chart, reporting a summary of the method and results of our systematic literature review.

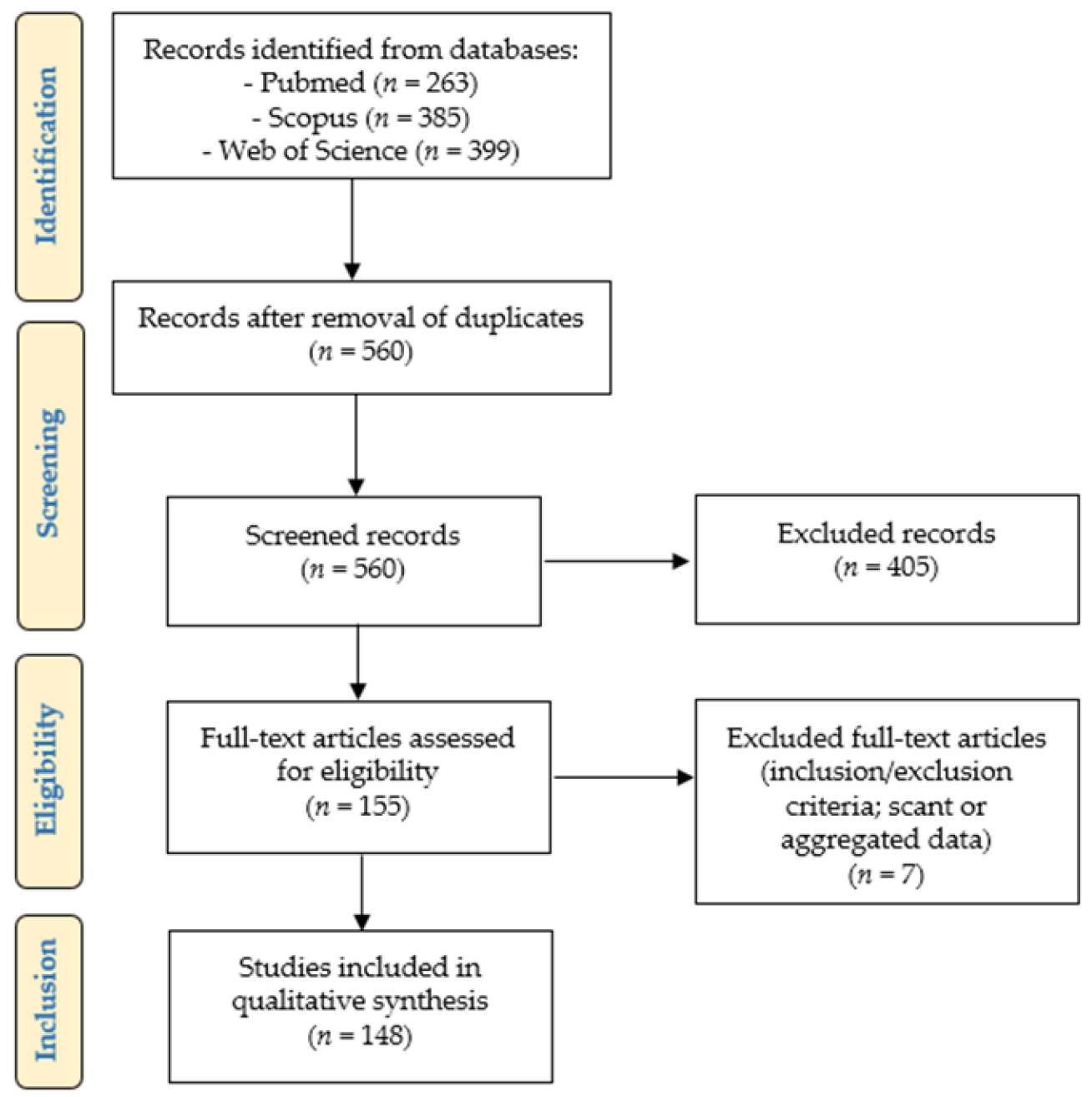

Figure 1. Systematic review of the literature: PRISMA flow-chart.

We identified 263 articles on Pubmed (https:// pubmed.ncbi.nlm.nih.gov; accessed on 8 May 2021), 385 articles on Scopus (https:/ / www.scopus.com/home.uri; accessed on 8 May 2021), and 399 articles on Web of Science databases (https:/ /login.webofknowledge. com; accessed on 8 May 2021). After duplicates removal, 560 records underwent first-step screening of titles and abstracts: 155 articles were found to be eligible for our study, and they were retrieved in full text format. After reading them, 7/155 papers were excluded, as they did not satisfy the inclusion criteria, or because they presented scant or aggregated data. 148 articles were finally included in our study [8-155].

\subsection{Experimental Studies: Intracellular Signaling Pathways Involved in PD-L1 Expression in PC}

Many articles investigated the role of the PD-1/PD-L1 axis on tumor and immune cells in PC cell lines and mouse models. Experimental studies revealed that the intracellular ERK/MEK, Akt-mTOR, NF-kB, WNT, and JAK/STAT pathways were involved in PD-L1 regulation in PC (Figure 2) [110]. 


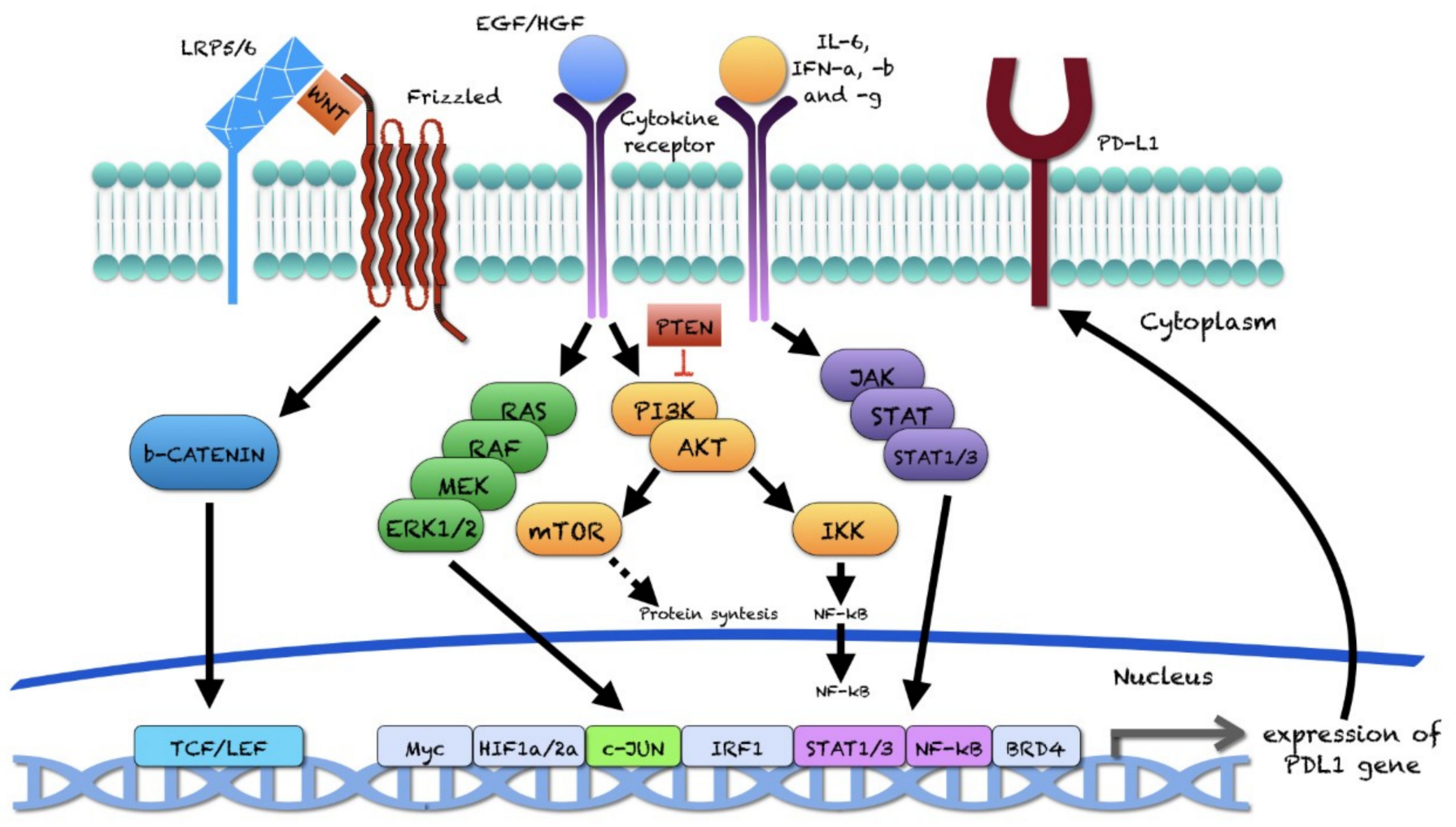

Figure 2. Intracellular signaling pathways involved in PD-L1 expression.

The different signaling pathways were investigated by variably using human and/or mouse PC cell lines, derived from either androgen-sensitive or androgen-resistant PCs. In particular, the ERK/MEK and Akt-mTOR pathways were studied only in human metastatic androgen-independent cell lines (PC3, DU145) [105,121], while the NF-kB and WNT pathways were additionally investigated in human metastatic androgen-sensitive cell lines (LNCaP) $[53,117,145]$. Finally, the JAK/STAT pathway was explored not only in human metastatic androgen-sensitive (LNCaP) and androgen-independent cell lines (PC3, DU145, C4-2, CWR22RV1, LASCPC, NCI-H660), but also in a primary mouse cell line (TRAMP-C2) $[13,65,97,126,131,134,136,143]$. All these studies agreed that the activation of ERK, NF-kB and JAK/STAT pathways leads to PD-L1 upregulation, regardless of the tumor sample type (primary vs. metastatic) and of the androgen responsiveness/resistance of the analyzed PC-cell lines. Indeed, treatment of PC-cell lines with NF-kB, MEK, JAK, or STAT inhibitors down-modulated PD-L1-expression. It has been documented that PTEN upregulation caused inhibition of mTOR and PD-L1 in mice injected with PC-cells overexpressing chemerin (a chemoattractant protein and PTEN-activator). The AKT-mTOR inhibition and the chemerin-induced PD-L1 downregulation caused a significant reduction of tumor growth in these preclinical models [105].

\subsection{Data from The Cancer Genome Atlas (TCGA) Analysis}

Some articles investigated the role of PD-L1 in human patients using data retrieved from the TCGA. The CD274 gene, encoding for PD-L1, is located on chromosome 9p24.1: genomic rearrangements may upregulate $C D 274$ expression, leading to enhanced immune escape of tumor cells [156]. Analysis of the data available on cBioPortal online database (https:/ / www.cbioportal.org/; accessed on 1 October 2021) revealed that 102/8590 (1.2\%) of PC cases included in this dataset harbored genetic alterations of CD274 gene, including mutations (6\%), amplifications (11\%) and deep deletions (83\%) (Figure 3). 

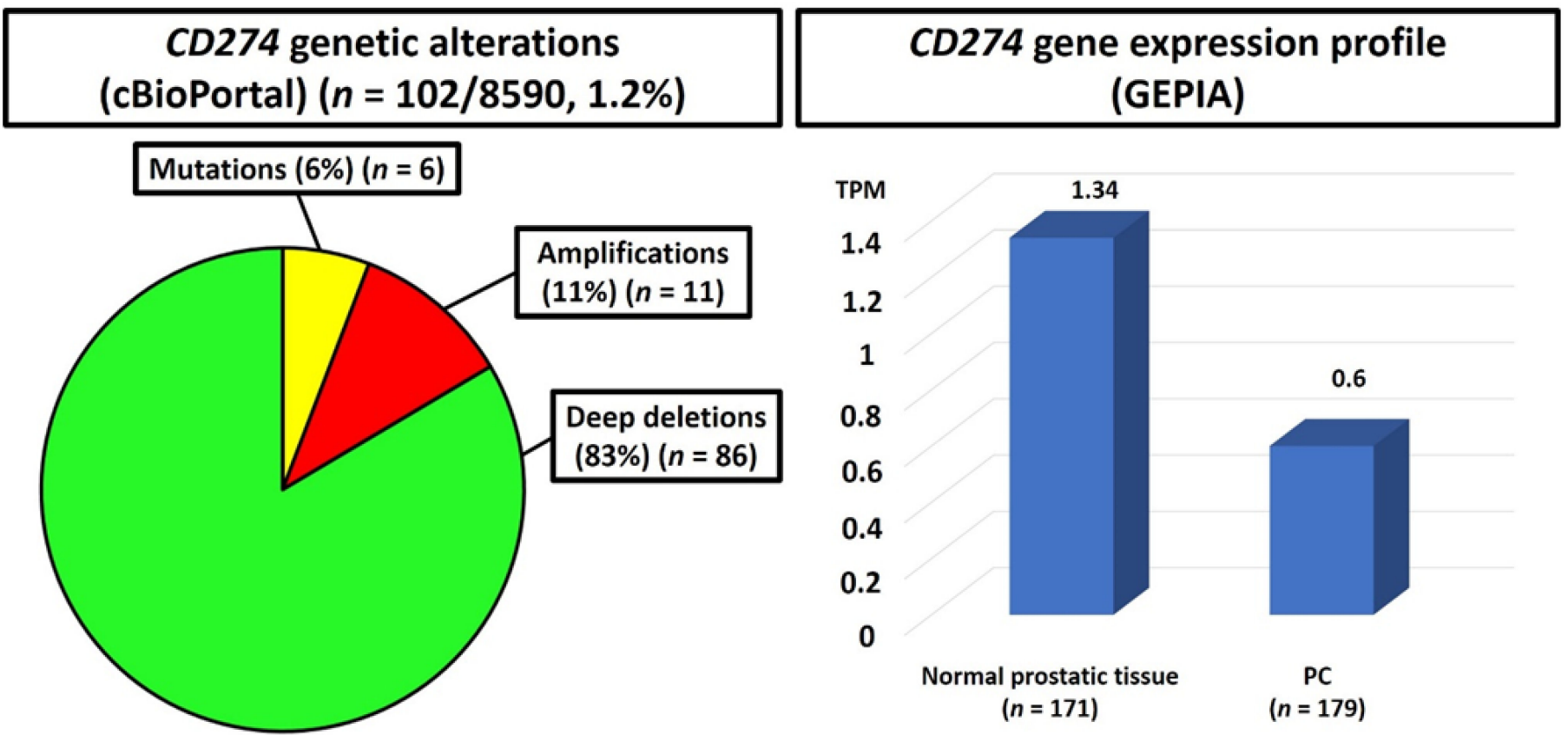

Figure 3. Results of big data analysis: CD274 genetic alterations ((left): cBioPortal; https:/ /www.cbioportal.org/ (accessed on 12 August 2021)) and gene expression profile ((right): GEPIA database; http:/ / gepia.cancer-pku.cn/index.html (accessed on 12 August 2021)). PC: prostate cancer; TPM: transcripts per millionset. On the right, the median TPM values of CD274 gene expression in normal prostatic tissue and PC are repoted above the respective histograms.

Analysis of GEPIA database (http:/ / gepia.cancer-pku.cn/index.html; accessed on 1 October 2021) revealed that the median values of $C D 274$ gene expression in normal prostatic tissue was higher than in PC $(1.34$ vs. 0.6 transcripts per millionset $)$ (Figure 3). Gevensleben et al. [86] analyzed the methylation of PD-L1 promoter (mPD-L1) in a TCGA-training cohort of 498 PCs and a validation group of 299 radical prostatectomy specimens: normal prostatic tissues showed lower levels of mPD-L1 compared to PC-samples. In another study, PD-L1 mRNA expression was significantly lower in PCs ( $n=492$, TCGA set; $n=110$, radical prostatectomy and biopsy samples of the authors series) than in bladder ( $n=404$, TCGA set) or renal carcinomas ( $n=534$, TCGA set): only the abstract was available [85].

Chromosome 9p gains are common DNA copy number aberrations, significantly associated with advanced tumor stage and regional lymph node metastases in sporadic PCs $[157,158]$. Budczies et al. identified a 7.8-Mbp region of 38 genes located in chromosome 9p24, including genes regulating cell cycle and immune-response in PC (such as $P D-L 1, P D-L 2$ and $J A K 2$ ). Across 22 tumor types originating from various districts (genitourinary, gastro-intestinal, gynecological, head and neck, brain, endocrine, pulmonary, etc.) (TCGA data), this region was co-amplified with PD-L1 in $>80 \%$ of tumors with focal PD-L1 copy number gains (CNGs). The authors found that PCs showed significant PD-L1 mRNA expression changes (1.8-fold change, FC, $p=0.0009)$, PD-L2 (1.6 FC, $p=0.002)$, and JAK2 (1.4 FC, $p=0.00017$ ) in cases with PD-L1 CNGs, compared to tumors lacking these gains [68]. PCs also showed upregulation of immune-system related genes (including ADAMDEC1, APLN, CCL4, CCL8, CXCL10, CXCL11, FCGR3A, GBP5, IDO1, IFI44L, IFNG, JAK2, KIF2C, $M E L K, P D-L 1, P D-L 2)$ and of genes regulating the cellular proliferation (including $A S P M$, CDC20, CDCA8, CDKN2A, CENPA, CENPF, CENPI, CLSPN, FAM83D, GTSE1, HAUS6, IFNG, KIF18B, KIF2C, MELK, MYBL2, NUF2, PLK1, SPC24, TPX2, TTK, UHRF2): however, it was unclear which specific genes were over-expressed in each of the 2 categories [68].

Meng et al. [19] analyzed various cohorts of PCs (also derived from TCGA) for a total number of 1557 cases, which were divided into 3 classes (immune-activated, immunesuppressed, and non-immune). The signatures of WNT/TGF- $\beta$, TGF- $\beta 1$, and extracellu- 
lar matrix cytokines (C-ECM) were more enriched in the immune-suppressed (stromalactivated) subtype than in the non-immune class $(p<0.05)$ : these cases showed increased expression of IL-11, TGFB1, and TGFB2, and high expression of tumor-infiltrating regulatory T cell (Treg) signatures $(p<0.05)$. The immune-activated class revealed high enrichment of Th17 cell infiltrate signature, the best recurrence-free survival outcomes, and potential benefit from anti-PD-1/PD-L1 treatment. Copy number alterations of immune checkpoints (such as PD-1, PD-L1, LGALS9, and CD48) positively correlated to immunocytes infiltrate. The immune class showed higher density of TILs $(p=0.001)$ and CD163+ cells (immune-suppressed group, $p<0.0001$; immune-activated subtype, $p=0.0018$ ), and increased PD-L1 expression $(p<0.001)$. In 2013, the U.S. FDA (Food and Drug Administration) approved the PAM50 molecular classifier for the clinical prognostic subclassification of breast cancer patients into luminal A, luminal B, HER2-enriched, and basal-like categories [159]. Meng et al. [19] applied this classifier to PC patients, finding that the immune-suppressed subtype included more luminal B-like cases, while the immuneactivated class comprised more luminal A-like PCs: the second group showed higher expression of immune checkpoint (PD-L1 and CTLA-4) and chemokine genes (CXCL9 and CXCL10).

CTHRC1 (Collagen Triple Helix Repeat Containing 1) encodes a protein potentially involved in vascular remodeling: CTHRC1 mRNA expression positively correlated to increased PD-1 and PD-L1 levels in a TCGA cohort [120].

TCGA-studies concerning the epigenetic regulation of PD-L1 in PC are better presented and discussed in other parts of our review (see Materials and Methods): here we report a brief summary of relevant data. In a series $(n=35)$, PD-L1 RNA levels were higher in metastatic (vs. primary) PC-samples, correlating to MLL3 expression (a histone modifier): this association was confirmed also by TCGA data $(p<0.01)$ [56]. Analysis of TCGA datasets found that PD-L1 expression was positively associated with LIF levels, which were stimulated by RNF165 (RING finger protein 165) gene transcripts, including a novel long non-coding RNA (lncAMPC) [104]. PCs overexpressing WDR5 (histone methylation regulator) were more frequently PD-L1+ by immunohistochemistry in a series of 262 PCs: a positive correlation between WDR5 and PD-L1 mRNA levels was also confirmed by a TCGA set $(n=374)$ [10]. Expression of PD-L1 and its positive regulators (EP300, CREBBP, IRF-1, and BRD4) negatively correlated with Grade Group in another study, including TCGA data [112]. Conversely, negative PD-L1 regulators (HDAC1, HDAC2, and HDAC3) seemed insignificant during cancer progression. Moreover, an inverse association was found between: (1) PD-L1, EP300, and CREBBP expression and overall survival; (2) PD-L1 and PD-1 expression and tumor purity; (3) PD-L1 and PD-1 expression and increased tumorinfiltrating immune cells [112]. In the abovementioned study of Gevensleben et al. [86], high mPD-L1 $(p=0.008)$ and high PD-L1 protein expression $(p=0.002)$ (analyzed as continuous variables) both correlated with shorter biochemical recurrence-free survival. mPD-L1 was also significantly associated with pT stage $(p=0.010)$ and Grade Group $(p=0.001)$. miR-197 and miR-200a-c positively correlated to PD-L1 mRNA levels, being inversely associated with mPD-L1. miR-34a inversely correlated to mPD-L1 and mRNA expression.

\subsection{Experimental Studies: Overview of Extracellular Factors Involved in PD-L1 Regulation in PC}

The extracellular regulators of PD-L1 expression, investigated in the published studies, included cytokines/chemokines (IL-6, Il-27, IL-17, IFN- $\gamma$, TNF- $\alpha$, chemerin), complement factors (C5a), soluble factors released by stromal cells (AREG, IL-6) or adipocytes, and hypoxia. Table 1 summarizes the effects of PD-L1 extracellular regulators in PC cell lines and experimental studies. 
Table 1. Extracellular factors involved in the regulation of PD-L1.

\begin{tabular}{|c|c|c|c|c|}
\hline Factor & Experiment Type & Cell Lines & $\begin{array}{l}\text { Effects on } \\
\text { PD-L1 }\end{array}$ & Studied Effect \\
\hline Check point & & & & \\
\hline Soluble PD-1 [149] & $\begin{array}{c}\text { Co-culture and } \\
\text { Docetaxel treatment }\end{array}$ & DU145 and Jurkat & Act. & $\begin{array}{l}\uparrow \text { Docetaxel } \\
\text { resistance }\end{array}$ \\
\hline \multicolumn{5}{|l|}{$\begin{array}{l}\text { Soluble factors produced by stromal } \\
\text { cells }\end{array}$} \\
\hline AREG [121] & $\begin{array}{l}\text { Conditioned } \\
\text { medium }\end{array}$ & DU145, PC3, LNCaP & $\uparrow$ & $\begin{array}{l}\uparrow \text { Proliferation, } \\
\text { migration and } \\
\text { invasion }\end{array}$ \\
\hline IL-6 [97] & $\begin{array}{l}\text { Conditioned } \\
\text { medium }\end{array}$ & Dentritic cells & $\uparrow$ & // \\
\hline \multicolumn{5}{|l|}{$\begin{array}{l}\text { Soluble factors produced by } \\
\text { adipocytes }\end{array}$} \\
\hline Not identified [136] & $\begin{array}{l}\text { Co-culture with } \\
\text { conditioned } \\
\text { medium }\end{array}$ & $\begin{array}{c}\text { C4-2 and NK; } \\
\text { CWR22Rv1 and NK }\end{array}$ & $\uparrow$ & $\downarrow$ NK cytotoxicity \\
\hline \multicolumn{5}{|l|}{$\begin{array}{l}\text { Soluble factors produced by } \\
\text { macrophages }\end{array}$} \\
\hline Not identified [134] & $\begin{array}{l}\text { Co-culture with } \\
\text { conditioned } \\
\text { medium }\end{array}$ & $\begin{array}{c}\text { C4-2 and NK; } \\
\text { CWR22Rv1 and NK }\end{array}$ & $\uparrow$ & $\downarrow$ NK cytotoxicity \\
\hline \multicolumn{5}{|l|}{$\begin{array}{l}\text { Cytokine/Chemokine and } \\
\text { Complement factors }\end{array}$} \\
\hline IL-27 [151] & Treatment & PC3 & $\uparrow$ & // \\
\hline $\begin{array}{c}\text { IFN- } \gamma \\
{[10,13,94,103,112,119,128,139,152]}\end{array}$ & Treatment & PC3 & $\uparrow$ & // \\
\hline IFN- $\gamma[94]$ & Treatment & $\begin{array}{l}\text { Vcap CWR22Rv1, } \\
\text { E006AA }\end{array}$ & $\uparrow$ & // \\
\hline IFN- $\gamma[126]$ & Treatment & TRAMP-C2 & $\uparrow$ & // \\
\hline IFN- $\gamma[13]$ & Treatment & LASCPC, NCI-H660 & $\uparrow$ & // \\
\hline IFN- $\gamma[126]$ & Treatment & DU145 & $=$ & // \\
\hline IFN- $\gamma[13,94,128]$ & Treatment & LNCaP & $=$ & // \\
\hline IFN- $\gamma[94]$ & Treatment & LAPC-4 & $=$ & // \\
\hline IFN- $\gamma[13]$ & Treatment & BPH1, C4-2, CWRR-1 & $=$ & $/ /$ \\
\hline IFN- $\gamma[10,94,112,119,152]$ & Treatment & DU145 & $\uparrow$ & // \\
\hline IFN- $\gamma[112]$ & Treatment & TRAMP-C2 Ras & $\uparrow$ & /1 \\
\hline IFN- $\gamma[106]$ & Treatment & TRAMP-C1, MyC-CaP & $\uparrow$ & // \\
\hline $\mathrm{Ab}$ anti-IL-6 [134-136] & Treatment & C4-2, CWR22Rv1 & $\downarrow$ & // \\
\hline IL-6 [135] & Treatment & C4-2, CWR22Rv1 & $\uparrow$ & /1 \\
\hline IL-17 [145] & Treatment & LNCaP & $\uparrow$ & // \\
\hline TNF- $\alpha[145]$ & Treatment & LNCaP & $\uparrow$ & // \\
\hline Chemerin [105] & Treatment of co-culture & DU145 and T & $\downarrow$ & $\uparrow \mathrm{T}$ cytotoxicity \\
\hline C5a [18] & Treatment & PC3, C4-2 & $\uparrow$ & // \\
\hline \multicolumn{5}{|l|}{ Hypoxia } \\
\hline [65] & Co-culture & $\begin{array}{l}\text { C4-2 and NK; } \\
\text { CWR22Rv1 and NK }\end{array}$ & $\uparrow$ & $\downarrow$ NK cytotoxicity \\
\hline
\end{tabular}

Act. Activation; $\uparrow$ Upregulation; $\downarrow$ Downregulation; = No alteration; // No effect was investigated.

Except for chemerin, all the abovementioned factors induced PD-L1 activation/ upregulation. Soluble PD-1 caused an increase in docetaxel resistance of PC-cell lines in a study [149]. AREG favored tumor cell proliferation, migration and invasion [121]. Soluble factors released from adipocytes or macrophages, and hypoxic stress, decreased the NK cell cytotoxicity $[65,134,136]$. Chemerin favored an increase of the T cell toxicity [105]. The number of performed studies widely varied among the abovementioned investigated factors. Moreover, some PC cell lines were preferentially used in experimental studies, while other cells lines were rarely tested. 
Concerning cytokines, the effects of IFN- $\gamma$ were the most investigated in both human and mouse cell lines. Increased serum levels of various cytokines were also observed in the circulation of castration-resistant PCs (CRPCs) patients, including FGF, EGF, IL-6, IL-10, GM-CSF, IGF, and TGF- $\beta$, sometimes along with their respective receptors: they have a role in promoting tumor progression and/or immune evasion [44,160]. IFN- $\gamma$, IL-5, IL-10, MIP- $1 \alpha$, and TNF- $\alpha$ were also increased in treatment-sensitive patients [44]. To our review, IL-6 [135], IL-17 [145], TNF- $\alpha$ [145], IL-27 [151] upregulated PD-L1 in cell lines.

\subsection{IFN- $\gamma$}

IFN- $\gamma$ is released by CD8+ T cells, NK cells and macrophages to enhance their effector functions by stimulating antigen processing, and increasing TILs differentiation [161]. However, IFN- $\gamma$ can be captured and used by tumor cells to paralyze T cells. To our review, concerning cytokines, the effects of IFN- $\gamma$ were the most investigated in both human and mouse PC cell lines.

The JAK-STAT signaling pathway is frequently over-activated in PC cell lines (especially if metastatic and androgen-resistant). PC cell lines can be classified as sensitive or insensitive to IFN- $\gamma$. Indeed, most of the experiments about IFN- $\gamma$ treatment were performed in metastatic androgen-insensitive PC cell lines. The published studies reported that treating IFN- $\gamma$-sensitive PC-cell lines with IFN- $\gamma$ induced PD-L1 expression via upregulation of the JAK/STAT pathway. In turn, PD-L1 can suppress the proliferation and functions of NK cells and cytotoxic T lymphocytes, causing T cell apoptosis [108,112]. These data also explained (at least in part) why a response to IFN- $\gamma$ was observed in the majority of in vitro experiments.

On the other hand, literature data also reported IFN- $\gamma$ insensitive PC cell lines. For some of them, alterations in the JAK/STAT pathway (deletions, inactivations, etc.) were described, including the loss of JAK1 gene expression in LNCaP cell lines [162]. According to our review, we were not able to find significant data correlating mutations in JAK/STAT pathway and PD-L1 in IFN- $\gamma$-insensitive PC cell lines. Table 2 reports the details of the performed studies, including IFN- $\gamma$ concentrations, time of treatment and the techniques used for IFN- $\gamma$ detection.

In the experimental study of Zhang et al., high RelB (a driver of the NF- $\mathrm{kB}$ alternative pathway) and PD-L1 levels correlated to the Gleason score of PCs. IFN- $\gamma$ may induce PD-L1 expression by promoting NF- $\mathrm{KB}$ pathway activation and RelB nuclear translocation, resulting in PD-L1 transcriptional activation [137].

Major histocompatibility complex (MHC) class I molecules promote the presentation of non-self antigens on cancer cell surface, favoring their immune recognition by CD8+ cytotoxic T lymphocytes: PC cells frequently downregulate MHC class I molecules to evade the immune detection [143,163-168]. Both HLA-ABC and PD-L1 are upregulated by IFN- $\gamma$ via STAT1 phosphorylation [168]. In the study of Liu et al., a JAK2-inhibitor failed to induce HLA-ABC and PD-L1 expression, while treatment with the MEK (mitogenactivated protein kinase/extracellular signal-regulated kinase) inhibitor PD0325901 did not upregulate HLA-ABC and PD-L1 [143].

Analyzing acinar and small cell neuroendocrine PCs (SCNPCs), Sun et al. found that SCNPCs revealed the highest levels of PD-L1, IDO-1 (indoleamine 2,3-dioxygenase), and $\mathrm{N}$-cadherin; globally, the first 2 markers were highly expressed in N-cadherin + PCs [13]. $\mathrm{N}$-cadherin modulated the IFN- $\gamma$-Receptor/JAK1/STAT1 pathway, upregulating the IFN$\gamma$-induced expression of JAK1, PD-L1 and IDO. It also increased the production of free fatty acids, promoting Tregs generation. Conversely, the JAK2-STAT3 signaling was only linked to IDO-1 expression in this study.

IDO catalyzes the rate-limiting step of Tryptophan catabolism to Kynurenine (an endogenous ligand of the aryl hydrocarbon receptor), regulating the acquired local and peripheral immune tolerance in physiological and pathological conditions [49,151]. 
Table 2. Effects of IFN- $\gamma$ stimulation on PD-L1 in PC-cell lines.

\begin{tabular}{|c|c|c|c|c|c|}
\hline Cell Lines & Origin & IFN- $\gamma$ Dose & Treatment Time & $\begin{array}{l}\text { Detection } \\
\text { Method }\end{array}$ & Effect on PD-L1 \\
\hline BPH1 [13] & Human & $50 \mathrm{mg} / \mathrm{mL}$ & $24 \mathrm{~h}$ & WB & $=$ \\
\hline CWR22Rv1 [94] & Human & $100 \mathrm{U} / \mathrm{mL}$ & $48 \mathrm{~h}$ & $\mathrm{FC}$ & $\uparrow$ \\
\hline CWRR-1 [13] & Human & $50 \mathrm{mg} / \mathrm{mL}$ & $24 \mathrm{~h}$ & WB & $=$ \\
\hline C4-2 [13] & Human & $50 \mathrm{mg} / \mathrm{mL}$ & $24 \mathrm{~h}$ & WB & $=$ \\
\hline DU145 [126] & Human & $0.5-10-20 \mathrm{ng} / \mathrm{mL}$ & $48 \mathrm{~h}$ & FC & $=$ \\
\hline DU145 [10] & Human & Not reported & Not indicated & RT-PCR, FC & $\uparrow$ \\
\hline DU145 [94] & Human & 100 U/mL & $48 \mathrm{~h}$ & $\mathrm{FC}$ & $\uparrow$ \\
\hline DU145 [112] & Human & $10 \mathrm{ng} / \mathrm{mL}$ & $24 \mathrm{~h}$ & WB, FC & $\uparrow$ \\
\hline DU145 [119] & Human & $100 \mathrm{U} / \mathrm{mL}$ & $48 \mathrm{~h}$ & FC & $\uparrow$ \\
\hline DU145 [152] & Human & $10 \mathrm{ng}$ & $24 \mathrm{~h}$ & FC & $\uparrow$ \\
\hline E006AA [94] & Human & $100 \mathrm{U} / \mathrm{mL}$ & $48 \mathrm{~h}$ & FC & $\uparrow$ \\
\hline LASCPC [13] & Human & $50 \mathrm{mg} / \mathrm{mL}$ & $24 \mathrm{~h}$ & WB & $\uparrow$ \\
\hline LAPC-4 [94] & Human & $100 \mathrm{U} / \mathrm{mL}$ & $48 \mathrm{~h}$ & FC & $=$ \\
\hline LNCaP [13] & Human & $50 \mathrm{mg} / \mathrm{mL}$ & $24 \mathrm{~h}$ & WB & $=$ \\
\hline LNCaP [94] & Human & $100 \mathrm{U} / \mathrm{mL}$ & $48 \mathrm{~h}$ & FC & $=$ \\
\hline LNCaP [128] & Human & $10-100 \mathrm{ng} / \mathrm{mL}$ & $24 \mathrm{~h}$ & FC & $=$ \\
\hline MyC-CaP [106] & Mouse & $0.1-1-10 \mathrm{ng} / \mathrm{mL}$ & $72 \mathrm{~h}$ & FC & $\uparrow$ \\
\hline NCI-H660 [13] & Human & $50 \mathrm{mg} / \mathrm{mL}$ & $24 \mathrm{~h}$ & WB & $\uparrow$ \\
\hline PC3 [10] & Human & Not reported & Not indicated & RT-PCR, FC & $\uparrow$ \\
\hline PC3 [13] & Human & $50 \mathrm{mg} / \mathrm{mL}$ & $24 \mathrm{~h}$ & WB & $\uparrow$ \\
\hline PC3 [94] & Human & $100 \mathrm{U} / \mathrm{mL}$ & $48 \mathrm{~h}$ & FC & $\uparrow$ \\
\hline PC3 [103] & Human & $20 \mathrm{ng} / \mathrm{mL}$ & $24 \mathrm{~h}$ & WB, FC & $\uparrow$ \\
\hline PC3 [112] & Human & $10 \mathrm{ng} / \mathrm{mL}$ & $24 \mathrm{~h}$ & WB, FC & $\uparrow$ \\
\hline PC3 [119] & Human & $100 \mathrm{U} / \mathrm{mL}$ & $48 \mathrm{~h}$ & FC & $\uparrow$ \\
\hline PC3 [128] & Human & $10-100 \mathrm{ng} / \mathrm{mL}$ & $24 \mathrm{~h}$ & FC & $\uparrow$ \\
\hline PC3 [139] & Human & $100 \mathrm{ng} / \mathrm{mL}$ & $24 \mathrm{~h}$ & RT-PCR, WB & $\uparrow$ \\
\hline PC3 [152] & Human & $10 \mathrm{ng}$ & $24 \mathrm{~h}$ & $\mathrm{FC}$ & $\uparrow$ \\
\hline TRAMP-C1 [106] & Mouse & $0.1-1-10 \mathrm{ng} / \mathrm{mL}$ & $72 \mathrm{~h}$ & FC & $\uparrow$ \\
\hline TRAMP-C2 [126] & Mouse & $0.5-10-20 \mathrm{ng} / \mathrm{mL}$ & $48 \mathrm{~h}$ & FC & $\uparrow$ \\
\hline $\begin{array}{c}\text { TRAMP-C2 Ras } \\
\text { [112] }\end{array}$ & Mouse & $10 \mathrm{ng} / \mathrm{mL}$ & $24 \mathrm{~h}$ & WB, FC & $\uparrow$ \\
\hline Vcap [94] & Human & $100 \mathrm{U} / \mathrm{mL}$ & $48 \mathrm{~h}$ & FC & $\uparrow$ \\
\hline
\end{tabular}

$\uparrow$ Upregulation/increase; = No alteration; FC: flow cytometry; RT-PCR: Real-Time Polymerase Chain Reaction analysis; WB: Western blot analysis.

\subsection{TGF- $\beta$}

Transforming growth factor $\beta$ (TGF- $\beta$ ) is a putative mediator of castration-resistance in preclinical PC-models. TGF- $\beta$ inhibits cell proliferation and induces apoptosis in prostatic epithelial cells. However, PC-cells do not express TGF- $\beta 1$ receptors, and this is compounded by the overexpression of TGF- $\beta$ [169]. Loss of TGF- $\beta 1$ effect on PC-cells is apparently associated with more advanced tumors and greater metastatic potential. Meng et al. [19] dichotomized their series into immune-activated and immune-suppressed subtypes based on the stromal signature, represented by the activation of WNT/TGF$\beta$, TGF- $\beta 1$, and C-ECMs. Patients in the immune-suppressed group showed the worst recurrence-free survival, increased expression of IL-11, TGFB1, and TGFB2, and enrichment of tumor-infiltrating Treg signatures $(p<0.01)$, while immune-activated PCs $(14.9-24.3 \%)$ might benefit from anti-PD-1/PD-L1 therapy, as to their higher expression of immune checkpoint (PD-L1 and CTLA-4) and chemokine genes (CXCL9 and CXCL10).

\subsection{IL-17 and TNF- $\alpha$}

IL-17 induces the intratumor infiltration by PD-1+ immune cells, and promotes PD-L1 expression by tumor cells [150]. Analyzing the PCs of PTEN-null mice, Yang et al. found that IL-17rc wild-type mice showed higher levels of PD-1, PD-L1, and PD-L2, developing more aggressive tumors than IL-17rc knockout mice [150].

IL-17- and TNF- $\alpha$-secreting Th17 cells seemed enriched in PC, potentially favoring an immunosuppressive TME. Some authors $[145,170]$ found that these 2 molecules induced 
PD-L1 protein expression in some PC cell lines (LNCaP), but only TNF- $\alpha$ increased the PDL1 mRNA levels. Conversely, PD-L2 protein and mRNA expression were not upregulated. The authors favored an individual (rather than cooperative) activity of IL-17 and TNF- $\alpha$ via the AKT and NF-kB pathways. Indeed, NF-kB or AKT inhibitors downregulated the IL-17/TNF $\alpha$-induced protein expression of PD-L1.

\section{8. $I L-27$}

IL-27 (IL-12 family member) is a heterodimer of p28 (IL-27A) and EBI3 (EBV-induced gene 3) chains, favoring the CD4+ T cells proliferation, and upregulating the expression of IL-12-receptor (thus inducing Th1 polarization). IL-27 directly inhibits cancer growth or invasiveness, showing immune-enhancing activity in different in vivo tumor models [151]. However, the IL-27-induced priming may convert naïve T cells into PD-L1+ Tregs, limiting the IL-17 production [171]. Carbotti et al. found that IL-27 induced low IDO (mRNA and protein) levels and PD-L1 expression in human PC cell lines (PC3).

\section{9. $I L-15$}

IL-15 is a pivotal cytokine in the development and homeostasis of intraepithelial and CD8+ T lymphocytes, NK, and NK/T cells: unlike IL-2, IL-15 does not expand Tregs.

In murine PC-models, the IL-15-mediated antitumor immune response seemed to recruit NK, CD8+, and CD4+ T cells in TME. Treatment of transgenic (TRAMP)-C2 murine PC models with a triple therapy (IL-15, anti-CTLA-4 and anti-PD-L1 antibodies) enhanced the CD8 + T cell cytotoxic activity and the antigen-specific IFN- $\gamma$ release, inhibiting the suppressive functions of CD4+/CD25+ and CD8+/CD122+ Tregs [153]. This therapeutic combination decreased the tumor growth and prolonged the survival of tumor-bearing animals. However, response to IL-15 often resulted in overproduction of proinflammatory cytokines (such as IL-6, IL-10, TNF- $\alpha$, and IFN- $\gamma$ ), which can sometimes lead to serious side effects in patients.

IL-10 is a key immunoregulator, suppressing $\mathrm{T}$ cell functions and inducing Tregs development, thus favoring tumor immune evasion and the lower frequency of $\mathrm{T}$ cells observed in pre-treatment patients. Combining IL-15 with anti-IL-10 or anti-TGF- $\beta$ drugs failed to improve the favorable effects of IL-15. Administration of IL-15 in combination with blockade of CTLA-4 and/or PD-1 inhibited the IL-10 secretion by T-cells. Although IL-15 expanded the numbers of NK1.1+ cells, anti-asialo-GM1 (injected to deplete these cells) did not influence the tumor growth, while CD8 depletion abrogated the antitumor effects of IL-15 and triple combination treatments. Moreover, TRAMP-C2 cells express high levels of MHC class I molecules, probably limiting the NK tumor-killing efficacy [153,172].

\subsection{0. $I L-6$}

IL-6 is a proinflammatory cytokine involved in immunoregulation, cell growth and differentiation, as well as in obesity-related insulin-resistance and chronic inflammatory condition: plasma IL-6 levels positively correlated to weight gain in humans [136]. In some studies, high levels of IL-6 and IL-6 receptor (IL6R) have been associated with more aggressive PCs (disease progression, castration-resistance) $[45,173]$.

IL-6 promotes immunosuppression and an androgen-independent phenotype $[45,173]$. In PC models, IL-6 activated the JAK/STAT3, MAPK (mitogen-activated protein kinase) and PI3K (phosphatidylinositol 3-kinase) pathways, as well as the androgen receptor (AR)mediated trascription (even in the absence of androgen ligands). Moreover, IL-6 is involved in the regulation of vascular endothelial growth factor (VEGF), neuroendocrine differentiation, epithelial-mesenchymal transition and metastatic progression of PC. IL-6 induced resistance of CRPC cells to the NK cell-mediated cytotoxicity via activation of the JAK/STAT3 pathway, modulating the PD-L1 and NKG2D-ligand levels in CRPC cells $[135,136,174]$. Finally, IL-6 induces the development of immunosuppressive myeloid-derived suppressor cells (MDSCs) or tumor-associated macrophages (TAMs): their immunosuppressive functions occur through a STAT3-mediated mechanism [45]. 


\subsection{Complement System and Hypoxia}

The complement system (CS) is activated in various malignancies. C5a is a CS-product, a leukocyte chemoattractant and an inflammatory mediator binding to the C5a receptor (C5aR; CD88), which is aberrantly expressed by cancer cells. C5a is also directly released from tumor cells through a cell membrane protease. $\mathrm{C} 5 \mathrm{a}-\mathrm{C} 5 \mathrm{aR}$ interactions enhance tumor growth, invasiveness, immune-evasion and metastatic behavior through motility activation, increased release of matrix metalloproteases, and activation of the PI3K/AKT pathway, leading to PD-L1 expression in PC-cells. C5a also recruits the MDSCs, which inhibit the antitumor CD8+ T-cell response and can express PD-L1 [18].

Hypoxia can induce neoangiogenesis, and promotes the epithelial-mesenchymal transition, invasion, and metastatic progression of PCs, decreasing the sensitivity to radiotherapy and chemotherapy [65]. Hypoxia is involved in the immune evasion mechanisms of a variety of tumors, by increasing Nanog and TGF- $\beta 1$ expression, regulating miRNA levels, and reducing the immune anti-tumor activity of $\mathrm{T}$ cells and macrophages. In PC cells lines, hypoxic conditions favored PD-L1 upregulation and NKG2D ligands downregulation on the surface of the tumor cells, thus inhibiting the tumor killing by activated NK cells [65].

\subsection{AREG}

Cytotoxic agents frequently trigger irreparable damage in peritumoral stromal cells, generating many cells displaying a "senescence-associated secretory phenotype" (SASP). SASP cells can favor tissue homeostasis by supporting tissue repair, wound healing, and immunosurveillance, but also contribute in developing aging-related complications (atherosclerosis, osteoarthritis, physical frailty, and systemic inflammation), and play an important role in the TME [175]. SASP cells secrete various soluble factors (cytokines, chemokines, growth factors, and proteases) favoring chemoresistance and sometimes immunosuppression in the treatment-damaged TME [121]. Amphiregulin (AREG) is a ligand and activator of the epidermal growth factor receptor, released by treatment-damaged senescent stromal cells as a soluble factor through extracellular vesicles (such as exosomes). AREG potently enhances the malignant behavior of various primary and metastatic tumors [176]. Mast cell-derived AREG potentiates the immunosuppressive competency of Tregs [177].

AREG induced PD-L1 expression in PC cell lines, causing exhaustion of cytotoxic $\mathrm{T}$ and NK cells [121]. In PC mouse models, AREG was produced by the tumor stroma after damage (chemotherapy, ionizing radiation, etc.), conferring resistance to immunosurveillance by increasing PD-L1 expression on cancer cells [121]. AREG is a hallmark SASP molecule and potential biomarker, being detectable in the blood of post-treatment cancer patients.

\section{Discussion}

3.1. Tumor Microenvironment and Mechanisms of Tumor Immune-Escape Mediated by the PD-1/PD-L1 Axis: An Overview

The TME is the tumor milieu, including immune cells, stromal/mesenchymal cells (such as activated fibroblasts, adipocytes, etc.), blood vessels, and extracellular matrix, as well as cytokines, chemokines, and other soluble factors released by each TME component. The interactions between these different TME elements are necessary for cancer growth and progression, enabling tumor cell immune evasion. Studies on TME have demonstrated that cancer cells can upregulate PD-L1 expression and interact with other TME components via PD1/PD-L1 and other pathways [157].

Figure 4 illustrates the interaction of tumor cells with the various cell types of the TME. 


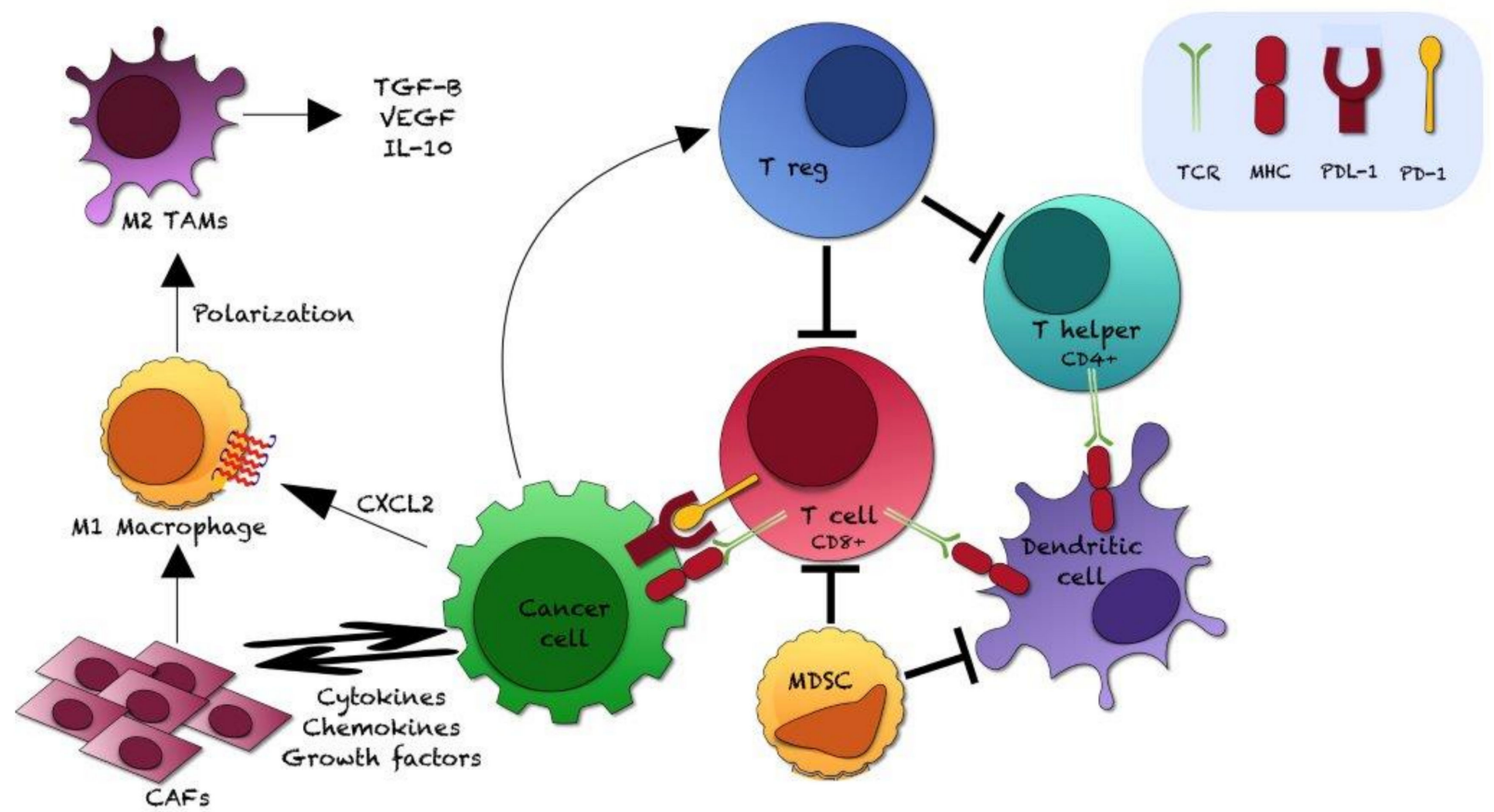

Figure 4. Interaction of prostate cancer cells with other cell types of the tumor microenvironment. CAFs: cancer-asssociated fibroblasts; CXCL2: Chemokine (C-X-C motif) ligand 2; IL-10: Interleukin-10; MDSC: myeloid-derived suppressor cell; MHC: major histocompatibility complex; TAMs: tumor-associated macrophages; T cell CD8+: CD8+ Cytotoxic T lymphocyte; TCR: T cell receptor; TGF- $\beta$ : Tumor Growth Factor $\beta$; T helper CD4+: CD4+ helper T lymphocyte; T reg: regulatory T cell; VEGF: Vascular-Endothelial Growth Factor; PD-1: programmed death 1; PDL-1: programmed death ligand 1.

Mechanisms of immune-escape by tumor cells mediated by the PD-1/PD-L1 axis include [65,79]:

(1) Suppression or inadequate activation/boosting of TILs activity:

- reduction of the proliferation of intratumoral cytotoxic $\mathrm{T}$ cells

- induction of CD8+ T cell exhaustion: CD8+ T cells may be present but incapable to mediate cytotoxic activity

- increase of CD8+ T cell apoptosis

- $\quad$ inhibition of Tregs apoptosis.

- B cells regulation

(2) Inhibition of function and activation of NK cells (which can kill tumor cells directly without dependence on antibodies or complement factors)

(3) Regulation of the secretion of soluble factors (inhibition of the production of effector cytokines; promotion of the secretion of immunosuppressive cytokines; chemotactic factors recruiting immunosuppressive cells; etc.)

(4) Immunosuppressive effects mediated by TAMs, MDSCs, dendritic cells and other cell-types (stromal cells, adipocytes, etc.): these cells may express PD-L1, recruit other immunosuppressive cells, secrete cytokines, and interact with tumor cells.

Blocking the PD-1/PD-L1 signaling by using immunotherapy drugs can prevent tumor immune escape, increasing the anti-tumor activity of immune cells by improving T-cell activation and cytotoxic T cell killing activity [108,123,126].

Even if immunotherapy is a promising option for advanced and castration-resistant tumors, not all the patients respond. Immunotherapy-refractory cases can be due to "adaptive" or "innate" immune resistance [178]. The "adaptive immune resistance" represents a situation in which PD-L1 upregulation is driven by proinflammatory molecules produced by immune cells. IFN- $\gamma$ and other soluble factors of the tumor microenvironment were able to upregulate PD-L1 in PC cells [10,13,94,103,106,112,119,126,128,139,152]. Conversely, when the "innate immune resistance" occurs, tumor cells autonomously upregulate PD-L1, 
under the influence of aberrant oncogenic pathways and without the induction of microenvironmental factors. In PCs, androgen ablation and loss of PTEN have been hypothesized as possible mechanisms of "innate immune resistance", but data were discordant [94,179,180]. Different strategies have been tested to overcome the resistance of PC cells to immunotherapy, such as the combination of multiple immune checkpoint inhibitors, or the association with chimeric antigen receptor T (CAR-T) cells therapy, oncolytic adenoviral vectors expressing immunomodulatory molecules, Stimulator of Interferon Genes (STING) agonists, TLR9 agonists, or epigenetic drugs (such as histone deacetylase inhibitors) [181,182]. Further information about experimental treatments in pre-clinical models and other promising therapy approaches are better described in other parts of our systematic literature review (see Materials and Methods).

\subsection{Intratumoral Lymphocytes}

The most characterized molecular interaction is between PD-L1 expressed on antigenpresenting cells and PD-1 expressed on T-cells: after PD-1/PD-L1 binding, the "Src homology region 2-containing protein tyrosine phosphatase" SHP-1 and SHP-2 are recruited on the PD-1 intracellular tail at its immunoreceptor tyrosine-based inhibitory and switch motifs. Due to the spatial proximity of the PD-1 tail with the T-cell receptor (TCR) complex, these phosphatases block the activation of signaling downstream to TCR by interacting with ZAP70, PI3K-AKT and RAS pathways. SHP2 activates the signal transduction (including the JAK/STAT pathway) of various growth factors and cytokines: it is an oncoprotein promoting proliferation and survival, but it may also act as a tumor suppressor in some tumors [143,183]. In PC cell lines, high SHP2/STAT3 and low SHP1/STAT1 (phosphorylated or not) expression were reported. At least in some PC cell lines, SHP2 phosphorylated STAT1 (negatively regulating HLA-ABC and PD-L1 expression) and ERK (activating this pathway). SHP2 depletion was associated with increased T-cell activation by co-culture of allogeneic healthy donor peripheral blood monocytes with SHP2 siRNA-pretreated tumor cells [143].

Despite the cytoplasmatic protein tail lacks the canonical motifs for signal transduction, PD-L1 reverse intracellular signaling has been recently demonstrated in immune cells, lymphomas and solid tumors. Some non-canonical signaling transduction motifs have been identified in the intracellular tail, being involved in cancer cell proliferation and survival, inhibition of autophagy, mTOR activation, and IFN- $\beta$ toxicity $[158,184]$.

PC frequently shows scant lymphocytic infiltrates or T-cell exclusion, while T-cells are restricted to the adjacent stroma and benign areas without direct contact between effectors and cancer cells. Moreover, impaired antigen presentation in tumors leads to inadequate activation and boosting of T cells [79]. Indeed, tumor cells can express molecules (such as IDO and PD-L1), impairing the CD8+ cytotoxic T cells activity [79]. Upregulation of PD-L1 on tumor and immunosuppressive cells can also represent a result of a productive antitumor immune response $[147,148]$. Tumor-specific CD8+ T cells may be present but exhausted, as demonstrated by expression of PD-1 and T-cell immunoglobulin and mucin-domain containing-3 (Tim-3) [79]. Furthermore, the identifiable immune cells usually have anergic and immunosuppressive phenotypes, including Tregs, M2-polarized TAMs, and MDSCs. Regulatory T cells include CD4+/CD25+/FoxP3+ Tregs and a subset of CD8+/CD122+ T cells which are critical in maintaining the peripheral self-tolerance (avoiding autoimmunity) by suppression of CD8+ cytotoxic T cells and IFN- $\gamma$ secretion; however, they also favor tumor immune-escape and progression, leading to poor outcomes: they are increased in peripheral blood and microenvironments of various tumors.

In some studies, PCs with poor prognosis had low infiltration of T- and dendritic cells, as well as high Tregs and TAMs levels; conversely, increased intratumor NK-cell infiltrates are associated with a low risk of progression. Improper TILs functionality (anergy, exhaustion or senescence) may also influence PC-immunosuppression. Activated NK cells release secretory lysosomes containing cytotoxic proteins (granzymes, perforin, etc.) to 
kill tumor cells, while cytotoxic T lymphocytes kill target cells by releasing granzymes or inducing Fas ligand-mediated apoptosis [108].

PD-L1 and VISTA are inhibitory molecules that can suppress murine and human T-cell responses. VISTA may represent a compensatory inhibitory pathway in PC after ipilimumab therapy [80]. Indeed, Gao et al. found significantly greater protein expression of PD-1, PD-L1, and VISTA in PC tissues treated with ipilimumab. PD-L1 and VISTA were upregulated in subsets of post-treatment intratumoral macrophages (CD163 + and ARG1 + , suggesting a M2-like phenotype) and in blood monocytes. High PD-L1 expression was found in CD4+ T cells, CD8+ T cells, and CD68+ macrophages [81], while VISTA may also be expressed by CD8+ cells [30].

\subsection{NK Cells}

Rare studies investigated the potential correlations between the NK cell-mediated cytotoxicity (NKCC) and PD-L1 expression in PC. Highly effective NK cells may be associated with good prognosis in metastatic CRPC-patients $[185,186]$. NKCC is independent of the tumor mutation burden, and NK cells play a pivotal role in exerting antigen-independent, innate immune responses, representing the early defense against cancer [135,185-187].

In addition to PD-L1 upregulation, suppression of NK group 2D (NKG2D)-activating ligands (including ULBP1, ULBP2, ULBP3, MHC class I chain-related molecules A and B, MICA and MICB) may represent another way of tumor escape from NKCC [188]. Conversely, upregulation of NKG2D ligands promotes the anti-tumor activity of NK cells [189]. Hypoxia inhibited the expression of NKG2D ligands on the surface of the PC cell lines, and thus the killing of tumor cells by activated NK cells [65]. IL-6 upregulates PD-L1 and simultaneously downregulates NKG2D ligands [135]. Treatment of CRPC cells and NK cells with THP-1 (conditioned media) revealed the same effect, decreasing the susceptibility of tumor cells to the NKCC $[134,135]$.

Unlike T cells, NK cells did not express high PD-1 levels; however, PD-1 exxpression can be increased upon incubation with tumor cells $[134,135]$. Leptin is a protein hormone expressed by adipocytes, with a role in regulating body weight, metabolism, and reproductive function: using conditioned media in vitro experiments on PC cells, some authors suggested that, like IL-6, this adipokine can induce resistance of CRPCs to NK cell action by activating the JAK/STAT3 pathway and regulating the PD-L1NKG2D ligand levels. Experimental studies suggested that inhibition of leptin or IL-6-JAK/STAT3 signaling in CRPC-cells enhances the anti-tumor NKCC via alteration of PD-L1/NKG2D-ligands levels $[65,134,136]$.

\subsection{Tumor-Associated Myeloid Cells}

Tumor-infiltrating myeloid cells such as TAMs or MDSCs secrete anti-inflammatory cytokines and are important components of the immunosuppressive TME, representing potential sensitive therapeutic targets for immunomodulation. Stress and inflammation can trigger and/or sustain STAT3 activity in PC cells and, especially, in tumor-associated myeloid cells [97]. Myeloid cells can be found in either low- or high-grade PCs, potentially having an early and sustained role in tumor progression. Myeloid cell infiltration into malignant tissues results from chemokines-mediated attraction, that is also regulated by tumor-stroma interaction [97,184].

TAMs can contribute to tumor progression, promoting genetic instability, supporting metastasis, and sometimes antagonizing the response to chemo- or radio-therapy. In PCs with numerous PD-L1+ cells, Scimeca et al. found a reduction and M2 polarization of TAMs, linked to the expression of PD-L1 [48]. M2 TAMs have an anti-inflammatory protumor effect, positively associated with aggressive pathologic features, malignant progression and recurrence after prostatectomy [47]. Indeed, they may exert immunosuppressive effects on T-cells through cytokine production and the PD-1/PD-L1 pathway, as by recruiting other immunosuppressive cells (MDSCs, immature dendritic cells, Tregs). Some authors found that TAMs express PD-L1/2, while others reported no change in the expression of 
immune checkpoint regulators (PD-L1 and B7-H3) in HLA-DR-/CD15+ MDSCs derived from patients' blood [45]. TAM may also decrease the NKCC to CRPC cells; NKG2D receptor on NK cells can be modulated by immunosuppressive TAMs, which may induce tumor immune escape from NK cell action $[48,135]$. FGF favors tumor cell dissemination, angiogenesis, and metastases in various types of solid cancers: elevated FGF levels correlated with an increase of M2 TAMs [45].

An experimental study found that EZH2 (Enhancer Of Zeste 2 Polycomb Repressive Complex 2 Subunit) inhibitors did not dramatically alter MDSC tumor infiltrate populations, but significantly reprogrammed TAM infiltrates, decreasing tumor-promoting M2 TAMs and increasing tumor-inhibiting M1 TAMs [155]. Colony-stimulating factor (CSF)-1 controls the differentiation, proliferation, and survival of macrophages by binding to CSF1 receptor, expressed on macrophages: increased $\triangle 133$ TP $53 \beta$ mRNA in PC was characterized by an immunosuppressive phenotype and increased frequency of PD-1, PD-L1, and CSF1 receptor-positive cells [40].

Cell death releases Toll-like receptor 9 (TLR9) ligands (mitochondrial DNA) while the TLR9/NF-kB-induced secretion of IL6 activates the STAT3 pathway. High TLR9 expression and STAT3 activation in immunosuppressive polymorphonuclear MDSCs (PMN-MDSC) accumulate in the blood of progressing metastatic/CRPC-patients. Moreover, in PC models, STAT3 activity in tumor-infiltrating MDSC correlated with increased PD-L1 levels and elevated plasma levels of IL6-type cytokines (such as LIF), suggesting a potential cross-talk mechanism promoting tumor immune evasion [190]. The TLR9+ PMN-MDSCs block T-cell proliferation and activity [130]. MYC oncogene expression and/or combined deletion of PTEN/SMAD4 or PTEN/TP53 also cause expansion of TAMs and MDSCs, promoting tumor immunotolerance and vascularization [130]. MDSC-secreted IL-23 is a potential driver of CRPC (at least in a subset of patients) via activation of AR signaling [191].

The abundance of circulating MDSCs correlated with prostate-specific antigen levels and metastasis in PC patients [81].

In the study of Sharma et al. [88], CD14- granulocytic MDSCs were significantly more common $(p<0.01)$ in pelvic lymph nodes than peripheral blood: this subgroup exhibited a high degree of immunosuppressive activity, as to the high STAT3 levels and PD-L1/2 expression. Conversely, no significant accumulation of CD4+/FOXP3+ Tregs was reported in pelvic lymph nodes, and CD14+ monocytic MDSCs were identified at rates similar to those detected in the peripheral blood of PC-patients.

PTX3 (TSG-14) (member of the long-pentraxin subfamily) is released by peripheral blood leukocytes and myeloid dendritic cells in response to proinflammatory stimuli (such as TNF- $\alpha$ and IL-1 $\beta$ ), but it may also have a role in inflammatory-related carcinogenesis, being expressed by either PC cells or intratumoral inflammatory infiltrates, especially macrophages. PTX3 overexpression in PC and other tumor types was considered as an unfavorable prognostic factor. Scimeca et al. reported increased numbers of PD-L1+ and PTX3+ cells in PCs (compared to benign lesions): PTX3 expression showed an inverse correlation with the number of PD-L1+ PC-cells. PD-L1+ PCs revealed decreased PD1+ lymphocytes and M2 TAMs [48].

\subsection{Dendritic Cells (DC) and Stromal Cells}

Tumor-associated stroma may be an immunosuppressive barrier to anticancer immunity, negatively influencing PC-progression by eliciting myeloid cell migration and altering their differentiation into fully functional DCs.

In the study of Spary et al., stromal cells produced significantly higher levels of CCL2, IL-6 and TGF- $\beta$ than epithelial cells. Indeed, PC-cells have minimal chemoattraction for myeloid cells; conversely, PC-stromal cells attract monocytes via CCL2 secretion in early PCs. Intratumoral CD68+ myeloid cells correlated with increased risk of PC-recurrence. CCL2 can be produced by various cell types, including epithelial, fibroblastic, endothelial and smooth muscle cells. CCL2 also activates CD11b+ monocytes, enhancing their IL-6 expression. IL-6 favors PD-L1 upregulation, and reciprocally increases CCL2 tissue levels, 
resulting in an amplification loop that promotes monocyte infiltration, malignant cell proliferation and tumor survival [97].

Fibroblast-derived IL-6 has been shown to affect the differentiation of monocytes into macrophages. Moreover, stromal-derived factors also promote differentiation of monocytes to DCs, inducing an immunosuppressive phenotype in DCs (CD14+/CD16+/CD68+/ CD124+/CD209+; PD-L1 overexpression). Thus, DCs become incapable of cross-presenting tumor antigens to T cells, inhibiting T-cell responses [97].

Stromal conditioned media may also influence the cytokine release from DCs. In IL-4 and GM-CSF treated monocytes, the immune-regulatory effect of stromal cells is mediated via the STAT3 pathway. In PCs, IL- 6 can be expressed by stromal and tumor cells, influencing the DC differentiation and function, which are inhibited by STAT3 activation. IL-10 generated CD14+ DC in vitro, favoring high PD-L1 expression levels. Monocytes exposed to stromal factors did not produce detectable amounts of IL-10; however, upon lipopolysaccharide stimulation, stromal factor-generated DCs (sDC) induce significantly more IL-10 and less IL-12 than their conventional DC-counterparts. sDC failed the cross-presentation of tumor-antigens to CD8+ T cells and suppressed the T-cell proliferation. sDCs showed significantly increased PD-L1 levels in a primarily STAT3 and IL-6-dependent manner. Inhibition of STAT3 restored CD14 downregulation during DC differentiation in the presence of PC-stromal cell-conditioned medium, and significantly inhibited the upregulation of PD-L1 on DCs [97].

\subsection{Adipocytes}

Obesity increases the risk of recurrence and castration-resistance in PC: periprostatic adipocytes may have paracrine effects on PC-tumor cells progression, by secretion of hormones and adipocyte-derived chemokines (adipokines) [136,192-194]. The obese state may favor a chronic inflammatory condition: adipokines are involved in inflammatory modulation (also attracting macrophages and T-cells), glucose and lipid metabolism, hypertension, or insulin sensitivity, and may also have a role in cancer progression.

In vitro experiments on PC cells suggested that adipokines/proinflammatory cytokines such as leptin (a protein hormone expressed by adipocytes, with a role in regulating body weight, metabolism, and reproductive function) and IL-6 can induce resistance of CRPCs to NK cell action via the JAK/STAT3 pathway, thus regulating the PD- L1/NKG2D ligand levels. IL-6 may also be involved in obesity-related insulin resistance: plasma IL-6 levels positively correlated to weight gain in humans [136].

\subsection{Comments on the Intracellular Signaling Pathways Involved in PD-L1 Expression}

In the perspectives of this review, experimental studies performed on human and mouse PC-cell lines revealed that the intracellular JAK/STAT, ERK/MEK, Akt-mTOR, NF-kB, and WNT pathways were involved in PD-L1 regulation in PC. Activation of ERK, NF-kB and JAK/STAT pathways leads to PD-L1 expression, regardless of the tumor sample (primary vs. metastatic) and of the androgen responsiveness/resistance of the analyzed PC-cell lines.

DNA double-strand breaks activate the STAT signaling [195,196]. STAT3 plays an important role in wound healing and tissue repair and it is frequently overactivated in malignant tumors, resulting in inflammation-driven repair, promotion of drug resistance and tumor progression. In some tumors (such as melanoma), inactivating mutations of JAK/STAT signaling are responsible of immunotherapy resistance [197-199], while data in PC are discordant. Persistent STAT activation was found in the majority of human PC-cell lines used for in vitro experiments, especially in metastatic androgen-resistant PC cell lines (such as PC3, DU145 and Vcap) [200]. A hyper-phosphorylation of STAT was also observed in human PC samples: STAT activation was evident in tumor areas, lacking in the normal tissue [200]. Constitutive STAT3 activity can result in tumor progression toward the CRPC phenotype and may be associated with poor overall survival [130]. An inverse correlation between activation of JAK/STAT pathway and AR expression was described in 
PC cell lines [200]. STAT3 levels may be also elevated in CRPC patients' serum, leading to transcriptional activation of AR [115,201,202]. Combined inhibition of STAT3-PD-L1 signaling can suppress CRPC immune escape, enhancing the NKCC [65].

Various cytokines (such as IL-6, IFN- $\alpha, \beta$, and $\gamma$ ) stimulate the JAK/STAT pathway, regulating cell proliferation, migration, differentiation, and inflammation. The JAK/STAT3 signaling is frequently over-activated in PC-cells, upregulating PD-L1 expression, suppressing the antigen presentation of DCs, and mediating other immunosuppressive effects. The binding of IL-6 to its receptor (IL-6R) activates the JAK/STAT signaling with STAT3 phosphorylation (pSTAT3): PD-L1 overexpression is significantly correlated to the pSTAT3 status [115]. In some studies, pSTAT3 and IL-6R expression were detected in $95 \%$ of metastatic CRPCs, being higher in bone vs. lymph node/visceral metastases [203]. Moreover, the most undifferentiated stem-like PC cells expressed the highest levels of IL-6 and IL-6R: blockade of JAK/STAT3 signaling could inhibit colony-forming and tumor initiation [204]. In addition, IL-6/JAK/STAT3 signaling could induce "pituitary tumor transforming gene 1" (PTTG1) overexpression with subsequent induction of epithelialmesenchymal transition, increasing the cancer stem cell population in $\mathrm{LNCaP}$ androgendependent PC cell lines. Moreover, STAT3 inhibition significantly increased the sensitivity of the DU-145 androgen-independent CRPC-cell line to bicalutamide (antiandrogen therapy) [126,203-206].

Ihle et al. reported that immune cells of blastic bone metastasis were enriched for pSTAT3, and multiple checkpoint inhibitor targets (B7-H4 VTCN1, PD-L1, PD-1, VISTA, OX40L, IDO-1 and ICOS CD278) [31]. Conversely, in lytic-type lesions, immune cells were enriched for phosphorylated AKT activity and components of the PI3K-AKT pathway.

The JAK/STAT signaling seems involved in PD-L1 expression not only in acinar PCs, but also in small cell neuroendocrine PCs through various mechanisms, including epigenetic methylation [111]. Owen et al. documented a loss of type I INF signaling in proliferating PC cells of bone metastases: this loss was associated with the suppression of tumor immunogenicity. The authors demonstrated that the restoration of tumor INF signaling by histone deacetylase inhibition increased the tumor cell visibility, promoted long-term antitumor immunity, and blocked cancer growth in a syngeneic mouse model [182].

Mitogen-activated protein kinases (MAPKs) are serine/threonine kinases mediating intracellular signaling associated with a variety of cellular activities including cell proliferation, differentiation, survival, death, and transformation. JNK and ERK are two of the major signal transducers involved in this pathway: JNK is generally associated with apoptosis induction, while ERK $1 / 2$ are frequently correlated to mitogenesis and inversely related to apoptosis [207]. JNK activity is altered in PCs, while ERK1/2 is typically phosphorylated in metastatic CRPCs [207-210]. The main oncogenes involved in this pathway rarely harbor genetic mutations, while amplifications of MAPK genes were found in about $1 / 3$ of cases [211,212]. RAS/MAPK pathway activating mutations are probably a "second hit" to the PTEN/PI3K/AKT pathway loss in metastatic PC [211].

PIK3CA mutations induce AKT-mTOR activation, increasing PD-L1 expression [156]. PTEN upregulation inhibits $\mathrm{mTOR}$, and PD-L1 has been documented in mice injected with PC-cells overexpressing chemerin (a PTEN-activator). The AKT-mTOR inhibition and chemerin-induced PD-L1 downregulation significantly reduced the tumor growth [105].

NF-kB factors are regulators involved in inflammatory and immune response, apoptosis and cell growth. NF-kB activation has been observed in various tumors, including PC [213-215]. NF-kB-inhibiting molecules can inhibit the growth of the androgenindependent PC cell lines; combination treatments with NF- $\mathrm{KB}$ and AR inhibitors have shown promising results [216,217]. Moreover, several protein kinase $C$ proteins have been implicated in PC development, and considered as putative therapeutic targets [216].

Finally, the Wnt signaling is involved in the embryological development and maintenance of stem cell populations. When the Wnt ligand (a secreted glycoprotein) binds to Frizzled receptors, a large cell surface "Wnt receptor complex" (WRC) is formed with LRP5/6. After $\beta$-catenin (hallmark of Wnt signaling) is stabilized by the activated WRC, it 
is translocated into the nucleus, where it binds to LEF/TCF transcription factors, displacing co-repressors and recruiting co-activators to Wnt target genes (including oncogenes such as $C-M Y C$ or $C C N D 1$ ). The Wnt/ $\beta$-catenin pathway could regulate PD-L1 expression in a direct manner, or indirectly via c-MYC binding to the PD-L1 promoter (activating its expression). CTLA- 4 is also a direct target gene of $\mathrm{Wnt} / \beta$-Catenin in melanoma: it increases the production of IFN- $\gamma$ by CD8+ and CD4+ TILs [218,219].

Epigenetic and genetic alterations in the Wnt pathway have been observed in several tumors, including PCs [220]. However, activating CTNNB1 ( $\beta$-Catenin) mutations have been rarely detected in PCs [221]. Loss of heterozygosity and mutations of APC gene may also influence this pathway [222]. Activating alterations have been observed more frequently in CRPCs than in treatment-naïve tumors [223-225]: targeting the Wnt/ $\beta$ catenin signaling may represent a potential therapeutic strategy against CRPCs.

PC can be associated with abnormal cholesterol metabolism and hypercholesterolemia: the low-density lipoprotein (LDL) receptor-related protein (LRP) family regulates lipid metabolism by receptor-mediated lipoprotein endocytosis. LRP1 and LRP5 could promote PC-progression. LRP11 over-expression in PC-cell lines activates $\beta$-catenin signaling, inducing PD-L1 expression: these effects seemed unrelated to the AR status. In addition, LRP11 induced immunosuppression in a co-culture system [117].

CTHRC1 has been proposed as a pivotal tumor promoter and activator of the planar cell polarity pathway via stabilization of the Wnt-receptor complex. It seems upregulated in various cancers (pancreas, stomach, liver, esophagus). In a PC series, CTHRC1 overexpression was associated with worse disease-free-survival, upregulation of PD-1 and PD-L1, increased inflammatory infiltrates (B cells, CD4+ T cells, macrophages, neutrophils and dendritic cells) and increased expression of matrix metalloproteinase-9, mucin 1 and SLCO2B1 (solute carrier organic anion transporter family member 2B1) genes [120].

\section{Materials and Methods}

In health care, increasing attention has been paid to systematic literature reviews (SLRs) and meta-analyses, which are used by clinicians to keep themselves up-to-date. Moreover, SLRs are often a starting point for further trials or for developing clinical guidelines. Finally, granting agencies may base the justification for research financial support on SLRs. For these reasons, impacting health care journals frequently ask contributing authors to conduct their SLRs according to the PRISMA guidelines (http:/ / www.prismastatement.org/; accessed on 8 May 2021), which include an evidence-based minimum set of items for reporting and represent a useful aid for a critical evaluation of the submitted manuscripts. So, we have conducted our SLR according to these guidelines, searching in multiple databases, as previously described in the various topics/contexts in which these guidelines are applicable [226-258].

Our study aimed to answer the following PICOS (Population, Intervention, Comparison, Outcomes) questions:

- Population: patients, tumor cell lines, or mouse models included in studies concerning the role of PD-L1 in PC;

- Intervention: any type of treatment;

- Comparison: no comparisons are expected;

- Outcomes: patient's status at last follow-up (no evidence of disease, alive with disease, dead of disease), response to therapy, biochemical recurrence-free survival, metastasis-free survival, cancer-specific survival, disease-free survival, clinical failurefree survival, overall-survival, progression-free survival; for experiments on PC cell lines and mouse models, any reported effect on cancer and immune cell migration, proliferation, viability, growth, resistance/response to therapy, cytotoxic/anti-tumor activity, PD-L1 expression, and mice/cell lines survival.

Study design: retrospective observational study (case series/reports, clinical trials, experimental studies). 
Eligibility/inclusion criteria: experimental studies (tumor cell lines, mouse models) or clinic-pathologic studies on human patients concerning the role PD-L1 in PCs.

Exclusion criteria: tumors not arising from the prostate; non-carcinomatous histotypes; studies not examining PD-L1; cases with uncertain diagnosis; review articles without new cases.

Information sources and search strategy: we searched for (PD-L1 AND (prostate OR prostatic) AND (adenocarcinoma OR adenocarcinomas OR cancer)) in Pubmed (all fields), Web of Science (Topic/Title), and Scopus (Title/Abstract/Keywords) databases. No limitations or additional filters were set. The bibliographic research ended on 8 May 2021.

Study selection: two independent reviewers selected the studies using a 2-steps screening method. In the 1st step, screening of titles and abstracts was performed to verify the eligibility/inclusion criteria, excluding irrelevant studies. In the 2nd step, full texts of relevant articles were screened by the 2 reviewers to verify study eligibility and inclusion criteria, avoiding duplications. Two other authors performed a manual screening of reference lists, to search for additional relevant papers. Finally, two authors checked the extracted data.

Object of the systematic review: (1) to update and summarize the literature concerning the role of PD-L1 on PC cells; (2) to report any information about clinic-pathological features, treatment strategies, and patients' outcomes.

Data collection process/data items: study-related (authors and year of publication) and case-related (tumor stage at presentation, Grade Group, type of specimen, treatment, test methods and results of PD-L1 expression, follow-up and outcomes, experiment type).

Statistical analysis: the collected data were reported as continuous or categorical variables. Categorical variables were summarized by frequency and percentage, while continuous variables by ranges, mean and median values. Time-to-recurrence was the time from primary treatment to disease recurrence. The survival status was the time from primary treatment to the last follow-up.

To better present the results of our systematic literature review and discuss the multiple interesting facets of PD-L1 expression by PC in detail, we have divided the presentation and discussion of our results into different articles, representing independent chapters of our work. They highlight various subtopics, including: PD-L1 immunohistochemical expression in PC cases, with discussion of pre-analytical and interpretation variables; correlations of PD-L1 expression with clinic-pathological features in PC patients; genetic and epigenetic regulation of PD-L1; data of pre-clinical studies (cell lines, mouse models) about the effects of experimental treatments on PD-L1 expression in PC cells; investigated correlations of PD-L1 expression with the status of mismatch repair system, BRCA, PTEN and other main genes in PC; PD-L1 expression in liquid biopsy samples; information of clinical trials, etc. We address the Readers to the other papers for further details on these subtopics [259-276].

\section{Conclusions}

TME includes immune (T, B, NK, dendritic), stromal/mesenchymal, endothelial, adipocytic cells, extracellular matrix, and cytokines/chemokines/soluble factors, which regulate various intracellular signaling pathways in tumor cells. TME influences PC growth and progression, enhancing tumor cell immune-evasion also through the activation of the PD-1/PD-L1 pathway. Immune-escape mechanisms of PC include suppression/exhaustion of tumor infiltrating cytotoxic T CD8+ lymphocytes, inhibition of tumor suppressive NK cells, increase in immune-suppressive immune cells (M2 macrophages, MDSCs, dendritic, stromal, adipocytic cells). IFN- $\gamma$, TGF- $\beta$, TNF- $\alpha$, IL-6, IL-17, IL-15, IL-27, complement factor $\mathrm{C} 5 \mathrm{a}$, and other soluble molecules secreted by TME components, as well as and hypoxia, influence PD-L1 regulation. Experimental studies using human and mouse PC cell lines (derived from either androgen-sensitive or androgen-resistant tumors) revealed that the JAK/STAT, ERK/MEK, Akt-mTOR, NF-kB, and WNT intracellular pathways were 
involved in PD-L1 upregulation in PC. Immunotherapy drugs can increase the anti-tumor activity of immune cells, preventing tumor immune-escape.

Author Contributions: Conceptualization, A.P., M.B., S.C. and M.Z. (Magda Zanelli); methodology, A.P., M.B., S.C., M.R. and M.P.B.; validation, A.P., A.C. and S.C.-P.; formal analysis, A.P., D.D.B., D.M.B. and F.S.; investigation, A.P., S.C. and M.B.; resources, A.P., M.Z. (Maurizio Zizzo) and A.S.; data curation, A.P., S.A. and C.C.R.; writing—original draft preparation, A.P., M.B, S.C., F.S and M.Z. (Magda Zanelli); writing-review and editing, A.P., M.B., S.C., D.D.B., A.B. and E.Z.; visualization, V.C., G.S., G.B., D.D.B. and B.M.; supervision, A.P., A.D.L. and M.L.; project administration, A.P., G.G., J.G., L.C. and G.C.; funding acquisition, A.P. and M.Z. (Magda Zanelli). All authors have read and agreed to the published version of the manuscript.

Funding: This research received no external funding.

Acknowledgments: Andrea Palicelli thanks his family for personal support. Daniel M. Berney is supported by Orchid and a PCUK grant.

Conflicts of Interest: The authors declare no conflict of interest.

\section{References}

1. Yu, H.; Fu, D.; Xu, P.P.; Cheng, S.; Wang, L.; Zhang, Y.Z.; Zhao, W.L. Implication of immune cell signature of tumor microenvironment in diffuse large B-cell lymphoma. Hematol. Oncol. 2021, 7, 31. [CrossRef]

2. Patsoukis, N.; Wang, Q.; Strauss, L.; Boussiotis, V.A. Revisiting the PD-1 pathway. Sci. Adv. 2020, 6, eabd2712. [CrossRef] [PubMed]

3. Dai, S.; Jia, R.; Zhang, X.; Fang, Q.; Huang, L. The PD-1/PD-Ls pathway and autoimmune diseases. Cell. Immunol. 2014, 290, 72-79. [CrossRef] [PubMed]

4. Falzarano, S.M.; Ferro, M.; Bollito, E.; Klein, E.A.; Carrieri, G.; Magi-Galluzzi, C. Novel biomarkers and genomic tests in prostate cancer: A critical analysis. Minerva Urol. Nefrol. 2015, 67, 211-231. [PubMed]

5. Di Donato, M.; Zamagni, A.; Galasso, G.; Di Zazzo, E.; Giovannelli, P.; Barone, M.V.; Zanoni, M.; Gunelli, R.; Costantini, M.; Auricchio, F.; et al. The androgen receptor/filamin A complex as a target in prostate cancer microenvironment. Cell Death Dis. 2021, 12, 127. [CrossRef] [PubMed]

6. Cioni, B.; Zwart, W.; Bergman, A.M. Androgen receptor moonlighting in the prostate cancer microenvironment. Endocr. Relat. Cancer 2018, 25, R331-R349. [CrossRef] [PubMed]

7. $\mathrm{Pu}, \mathrm{Y}$;; $\mathrm{Xu}, \mathrm{M} . ;$ Liang, Y.; Yang, K.; Guo, Y.; Yang, X.; Fu, Y.X. Androgen receptor antagonists compromise $\mathrm{T}$ cell response against prostate cancer leading to early tumor relapse. Sci. Transl. Med. 2016, 8, 333. [CrossRef]

8. National Comprehensive Cancer Network (NCCN) Clinical Practice Guidelines in Oncology. Prostate Cancer, Version 2.202117 February 2021. Available online: https://www.nccn.org/professionals/physician_gls/pdf/prostate.pdf (accessed on 29 May 2021).

9. Santandrea, G.; Piana, S.; Valli, R.; Zanelli, M.; Gasparini, E.; De Leo, A.; Mandato, V.D.; Palicelli, A. Immunohistochemical Biomarkers as a Surrogate of Molecular Analysis in Ovarian Carcinomas: A Review of the Literature. Diagnostics 2021, 11, 199. [CrossRef]

10. De Leo, A.; Santini, D.; Ceccarelli, C.; Santandrea, G.; Palicelli, A.; Acquaviva, G.; Chiarucci, F.; Rosini, F.; Ravegnini, G.; Pession, A.; et al. What Is New on Ovarian Carcinoma: Integrated Morphologic and Molecular Analysis Following the New 2020 World Health Organization Classification of Female Genital Tumors. Diagnostics 2021, 11, 697. [CrossRef] [PubMed]

11. Foda, A.A.; Palicelli, A.; Shebl, A.; Boldorini, R.; Elnaghi, K.; ElHawary, A.K. Role of ERCC1 expression in colorectal adenomacarcinoma sequence and relation to other mismatch repair proteins expression, clinicopathological features and prognosis in mucinous and non-mucinous colorectal carcinoma. Indian J. Pathol. Microbiol. 2019, 62, 405-412. [CrossRef]

12. Sharma, P.; Pachynski, R.K.; Narayan, V.; Fléchon, A.; Gravis, G.; Galsky, M.D.; Mahammedi, H.; Patnaik, A.; Subudhi, S.K.; Ciprotti, M.; et al. Nivolumab Plus Ipilimumab for Metastatic Castration-Resistant Prostate Cancer: Preliminary Analysis of Patients in the CheckMate 650 Trial. Cancer Cell 2020, 38, 489-499.e3. [CrossRef]

13. Antonarakis, E.S.; Piulats, J.M.; Gross-Goupil, M.; Goh, J.; Ojamaa, K.; Hoimes, C.J.; Vaishampayan, U.; Berger, R.; Sezer, A.; Alanko, T.; et al. Pembrolizumab for Treatment-Refractory Metastatic Castration-Resistant Prostate Cancer: Multicohort, Open-Label Phase II KEYNOTE-199 Study. J. Clin. Oncol. Off. J. Am. Soc. Clin. Oncol. 2020, 38, 395-405. [CrossRef]

14. Zhou, Q.; Chen, X.; He, H.; Peng, S.; Zhang, Y.; Zhang, J.; Cheng, L.; Liu, S.; Huang, M.; Xie, R.; et al. WD repeat domain 5 promotes chemoresistance and Programmed Death-Ligand 1 expression in prostate cancer. Theranostics 2021, 11, 4809-4824. [CrossRef] [PubMed]

15. Vardaki, I.; Corn, P.; Gentile, E.; Song, J.H.; Madan, N.; Hoang, A.; Parikh, N.; Guerra, L.; Lee, Y.C.; Lin, S.C.; et al. Radium223 Treatment Increases Immune Checkpoint Expression in Extracellular Vesicles from the Metastatic Prostate Cancer Bone Microenvironment. Clin. Cancer Res. Off. J. Am. Assoc. Cancer Res. 2021, 27, 3253-3264. [CrossRef] [PubMed] 
16. Shim, K.H.; Kwon, J.E.; Park, S.G.; Choo, S.H.; Kim, S.J.; Kim, S.I. Cell membrane and nuclear expression of programmed death ligand-1 in prostate needle biopsy tissue in prostate cancer patients undergoing primary radiation therapy. Urol. Oncol. 2021, 39, 298.e13-298.e20. [CrossRef] [PubMed]

17. Sun, Y.; Jing, J.; Xu, H.; Xu, L.; Hu, H.; Tang, C.; Liu, S.; Wei, Q.; Duan, R.; Guo, J.; et al. N-cadherin inhibitor creates a microenvironment that protect TILs from immune checkpoints and Treg cells. J. Immunother. Cancer 2021, 9, e002138. [CrossRef] [PubMed]

18. Zavridou, M.; Strati, A.; Bournakis, E.; Smilkou, S.; Tserpeli, V.; Lianidou, E. Prognostic Significance of Gene Expression and DNA Methylation Markers in Circulating Tumor Cells and Paired Plasma Derived Exosomes in Metastatic Castration Resistant Prostate Cancer. Cancers 2021, 13, 780. [CrossRef]

19. Brady, L.; Kriner, M.; Coleman, I.; Morrissey, C.; Roudier, M.; True, L.D.; Gulati, R.; Plymate, S.R.; Zhou, Z.; Birditt, B.; et al. Interand intra-tumor heterogeneity of metastatic prostate cancer determined by digital spatial gene expression profiling. Nat. Commun. 2021, 12, 1426. [CrossRef] [PubMed]

20. Zhang, T.; Agarwal, A.; Almquist, R.G.; Runyambo, D.; Park, S.; Bronson, E.; Boominathan, R.; Rao, C.; Anand, M.; Oyekunle, T.; et al. Expression of immune checkpoints on circulating tumor cells in men with metastatic prostate cancer. Biomark. Res. 2021, 9, 14. [CrossRef]

21. Petrylak, D.P.; Loriot, Y.; Shaffer, D.R.; Braiteh, F.; Powderly, J.; Harshman, L.C.; Conkling, P.; Delord, J.P.; Gordon, M.; Kim, J.W.; et al. Safety and Clinical Activity of Atezolizumab in Patients with Metastatic Castration-Resistant Prostate Cancer: A Phase I Study. Clin. Cancer Res. Off. J. Am. Assoc. Cancer Res. 2021, 27, 3360-3369. [CrossRef]

22. Imamura, R.; Kitagawa, S.; Kubo, T.; Irie, A.; Kariu, T.; Yoneda, M.; Kamba, T.; Imamura, T. Prostate cancer C5a receptor expression and augmentation of cancer cell proliferation, invasion, and PD-L1 expression by C5a. Prostate 2021, 81, 147-156. [CrossRef]

23. Meng, J.; Zhou, Y.; Lu, X.; Bian, Z.; Chen, Y.; Zhou, J.; Zhang, L.; Hao, Z.; Zhang, M.; Liang, C. Immune response drives outcomes in prostate cancer: Implications for immunotherapy. Mol. Oncol. 2021, 15, 1358-1375. [CrossRef] [PubMed]

24. Wong, J.K.; MacFarlane, A.; Devarajan, K.; Shulman, R.M.; Alpaugh, R.K.; Burbure, N.; Hallman, M.A.; Geynisman, D.M.; Horwitz, E.M.; Campbell, K.; et al. Hypofractionated Short Course Radiation Treatment Results in Systemic Immune Activation and Upregulation of the PD-1/PD-L1 Exhaustion Axis: A Prospective Pilot Study in Early Stage Prostate Cancer Patients. Int. J. Radiat. Oncol. Biol. Phys. 2020, 108, S120. [CrossRef]

25. Graff, J.N.; Beer, T.M.; Alumkal, J.J.; Slottke, R.E.; Redmond, W.L.; Thomas, G.V.; Thompson, R.F.; Wood, M.A.; Koguchi, Y.; Chen, Y.; et al. A phase II single-arm study of pembrolizumab with enzalutamide in men with metastatic castration-resistant prostate cancer progressing on enzalutamide alone. J. Immunother. Cancer 2020, 8, e000642. [CrossRef] [PubMed]

26. Chen, Q.H.; Li, B.; Liu, D.G.; Zhang, B.; Yang, X.; Tu, Y.L. LncRNA KCNQ1OT1 sponges miR-15a to promote immune evasion and malignant progression of prostate cancer via up-regulating PD-L1. Cancer Cell Int. 2020, 20, 394. [CrossRef]

27. Wang, Q.; Ye, Y.; Yu, H.; Lin, S.H.; Tu, H.; Liang, D.; Chang, D.W.; Huang, M.; Wu, X. Immune checkpoint-related serum proteins and genetic variants predict outcomes of localized prostate cancer, a cohort study. Cancer Immunol. Immunother. 2021, 70, 701-712. [CrossRef]

28. Han, H.J.; Li, Y.R.; Roach, M., 3rd; Aggarwal, R. Dramatic response to combination pembrolizumab and radiation in metastatic castration resistant prostate cancer. Ther. Adv. Med. Oncol. 2020, 12, 1758835920936084. [CrossRef] [PubMed]

29. Vicier, C.; Ravi, P.; Kwak, L.; Werner, L.; Huang, Y.; Evan, C.; Loda, M.; Hamid, A.A.; Sweeney, C.J. Association between CD8 and PD-L1 expression and outcomes after radical prostatectomy for localized prostate cancer. Prostate 2021, 81, 50-57. [CrossRef]

30. Ryan, S.T.; Zhang, J.; Burner, D.N.; Liss, M.; Pittman, E.; Muldong, M.; Shabaik, A.; Woo, J.; Basler, N.; Cunha, J.; et al. Neoadjuvant rituximab modulates the tumor immune environment in patients with high risk prostate cancer. J. Transl. Med. 2020, 18, 214. [CrossRef]

31. Sharma, M.; Yang, Z.; Miyamoto, H. Loss of DNA mismatch repair proteins in prostate cancer. Medicine 2020, 99 , e20124. [CrossRef]

32. Wagle, M.C.; Castillo, J.; Srinivasan, S.; Holcomb, T.; Yuen, K.C.; Kadel, E.E.; Mariathasan, S.; Halligan, D.L.; Carr, A.R.; Bylesjo, M.; et al. Tumor Fusion Burden as a Hallmark of Immune Infiltration in Prostate Cancer. Cancer Immunol. Res. 2020, 8 , 844-850. [CrossRef] [PubMed]

33. Obradovic, A.Z.; Dallos, M.C.; Zahurak, M.L.; Partin, A.W.; Schaeffer, E.M.; Ross, A.E.; Allaf, M.E.; Nirschl, T.R.; Liu, D.; Chapman, C.G.; et al. T-Cell Infiltration and Adaptive Treg Resistance in Response to Androgen Deprivation With or Without Vaccination in Localized Prostate Cancer. Clin. Cancer Res. Off. J. Am. Assoc. Cancer Res. 2020, 26, 3182-3192. [CrossRef] [PubMed]

34. Goswami, S.; Walle, T.; Cornish, A.E.; Basu, S.; Anandhan, S.; Fernandez, I.; Vence, L.; Blando, J.; Zhao, H.; Yadav, S.S.; et al. Immune profiling of human tumors identifies CD73 as a combinatorial target in glioblastoma. Nat. Med. 2020, $26,39-46$. [CrossRef]

35. Ihle, C.L.; Provera, M.D.; Straign, D.M.; Smith, E.E.; Edgerton, S.M.; Van Bokhoven, A.; Lucia, M.S.; Owens, P. Distinct tumor microenvironments of lytic and blastic bone metastases in prostate cancer patients. J. Immunother. Cancer 2019, 7, 293. [CrossRef]

36. Ross, A.E.; Hurley, P.J.; Tran, P.T.; Rowe, S.P.; Benzon, B.; Neal, T.O.; Chapman, C.; Harb, R.; Milman, Y.; Trock, B.J.; et al. A pilot trial of pembrolizumab plus prostatic cryotherapy for men with newly diagnosed oligometastatic hormone-sensitive prostate cancer. Prostate Cancer Prostatic Dis. 2020, 23, 184-193. [CrossRef] 
37. Bryce, A.H.; Dronca, R.S.; Costello, B.A.; Infante, J.R.; Ames, T.D.; Jimeno, J.; Karp, D.D. PT-112 in advanced metastatic castrateresistant prostate cancer (mCRPC), as monotherapy or in combination with PD-L1 inhibitor avelumab: Findings from two phase I studies. J. Clin. Oncol. 2020, 38 (Suppl. 6), 83. [CrossRef]

38. Abdul Sater, H.; Marté, J.L.; Donahue, R.N.; Walter-Rodriguez, B.; Heery, C.R.; Steinberg, S.M.; Cordes, L.M.; Chun, G.; Karzai, F.; Bilusic, M.; et al. Neoadjuvant PROSTVAC prior to radical prostatectomy enhances T-cell infiltration into the tumor immune microenvironment in men with prostate cancer. J. Immunother. Cancer 2020, 8, e000655. [CrossRef] [PubMed]

39. Sharma, M.; Yang, Z.; Miyamoto, H. Immunohistochemistry of immune checkpoint markers PD-1 and PD-L1 in prostate cancer. Medicine 2019, 98, e17257. [CrossRef]

40. Shaw, K.; Calagua, C.; Russo, J.; Einstein, D.; Balk, S.; Ye, H. Tumor PD-L1 Expression is Detected in a Significant Subset of High-Risk Localized and Metastatic Prostate Cancer but is Rare in Ductal Subtype. Abstracts from USCAP 2019: Genitourinary Pathology (including renal tumors) (776-992). Mod. Pathol. 2019, 32, 143-144.

41. Matveev, V.B.; Kirichek, A.A.; Safronova, V.M.; Khafizov, K.O.; Filippova, M.G.; Lyubchenko, L.N. [Impact of PD-L1 status on the long-term outcomes of radical treatment of patients with prostate cancer]. Urologiia 2019, 4, 51-57. [CrossRef]

42. Matveev, V.; Kirichek, A.; Safronova, V.; Kokosadze, N.; Khalmurzaev, O.; Kamolov, B.; Liubchenko, L. The prognostic value of tumor PD-L1 status in patients with metastatic prostate cancer. Cancer Urol. 2019, 15, 57-65. [CrossRef]

43. Iacovelli, R.; Ciccarese, C.; Brunelli, M.; Bogina, G.; Munari, E.; Bimbatti, D.; Mosillo, C.; Fantinel, E.; Bria, E.; Martignoni, G.; et al. PD-L1 Expression in De Novo Metastatic Castration-sensitive Prostate Cancer. J. Immunother. 2019, 42, 269-273. [CrossRef] [PubMed]

44. Kazantseva, M.; Mehta, S.; Eiholzer, R.A.; Gimenez, G.; Bowie, S.; Campbell, H.; Reily-Bell, A.L.; Roth, I.; Ray, S.; Drummond, C.J.; et al. The $\Delta 133$ p53 $\beta$ isoform promotes an immunosuppressive environment leading to aggressive prostate cancer. Cell Death Dis. 2019, 10, 631. [CrossRef] [PubMed]

45. Lindh, C.; Kis, L.; Delahunt, B.; Samaratunga, H.; Yaxley, J.; Wiklund, N.P.; Clements, M.; Egevad, L. PD-L1 expression and deficient mismatch repair in ductal adenocarcinoma of the prostate. APMIS Acta Pathol. Microbiol. Immunol. Scand. 2019, 127, 554-560. [CrossRef] [PubMed]

46. Richardsen, E.; Andersen, S.; Al-Saad, S.; Rakaee, M.; Nordby, Y.; Pedersen, M.I.; Ness, N.; Ingebriktsen, L.M.; Fassina, A.; Taskén, K.A.; et al. Low Expression of miR-424-3p is Highly Correlated with Clinical Failure in Prostate Cancer. Sci. Rep. 2019, 9, 10662. [CrossRef] [PubMed]

47. Xian, P.; Ge, D.; Wu, V.J.; Patel, A.; Tang, W.W.; Wu, X.; Zhang, K.; Li, L.; You, Z. PD-L1 instead of PD-1 status is associated with the clinical features in human primary prostate tumors. Am. J. Clin. Exp. Urol. 2019, 7, 159-169.

48. Li, H.; Wang, Z.; Zhang, Y.; Sun, G.; Ding, B.; Yan, L.; Liu, H.; Guan, W.; Hu, Z.; Wang, S.; et al. The Immune Checkpoint Regulator PDL1 is an Independent Prognostic Biomarker for Biochemical Recurrence in Prostate Cancer Patients Following Adjuvant Hormonal Therapy. J. Cancer 2019, 10, 3102-3111. [CrossRef]

49. Pal, S.K.; Moreira, D.; Won, H.; White, S.W.; Duttagupta, P.; Lucia, M.; Jones, J.; Hsu, J.; Kortylewski, M. Reduced T-cell Numbers and Elevated Levels of Immunomodulatory Cytokines in Metastatic Prostate Cancer Patients De Novo Resistant to Abiraterone and/or Enzalutamide Therapy. Int. J. Mol. Sci. 2019, 20, 1831. [CrossRef]

50. Abida, W.; Cheng, M.L.; Armenia, J.; Middha, S.; Autio, K.A.; Vargas, H.A.; Rathkopf, D.; Morris, M.J.; Danila, D.C.; Slovin, S.F.; et al. Analysis of the Prevalence of Microsatellite Instability in Prostate Cancer and Response to Immune Checkpoint Blockade. JAMA Oncol. 2019, 5, 471-478. [CrossRef]

51. Zhao, S.G.; Lehrer, J.; Chang, S.L.; Das, R.; Erho, N.; Liu, Y.; Sjöström, M.; Den, R.B.; Freedland, S.J.; Klein, E.A.; et al. The Immune Landscape of Prostate Cancer and Nomination of PD-L2 as a Potential Therapeutic Target. J. Natl. Cancer Inst. 2019, 111, 301-310. [CrossRef]

52. Scimeca, M.; Bonfiglio, R.; Urbano, N.; Cerroni, C.; Anemona, L.; Montanaro, M.; Fazi, S.; Schillaci, O.; Mauriello, A.; Bonanno, E. Programmed death ligand 1 expression in prostate cancer cells is associated with deep changes of the tumor inflammatory infiltrate composition. Urol. Oncol. 2019, 37, e19-e297. [CrossRef]

53. Jung, K.H.; LoRusso, P.; Burris, H.; Gordon, M.; Bang, Y.J.; Hellmann, M.D.; Cervantes, A.; Ochoa de Olza, M.; Marabelle, A.; Hodi, F.S.; et al. Phase I Study of the Indoleamine 2,3-Dioxygenase 1 (IDO1) Inhibitor Navoximod (GDC-0919) Administered with PD-L1 Inhibitor (Atezolizumab) in Advanced Solid Tumors. Clin. Cancer Res. Off. J. Am. Assoc. Cancer Res. 2019, 25, 3220-3228. [CrossRef]

54. Mo, R.J.; Han, Z.D.; Liang, Y.K.; Ye, J.H.; Wu, S.L.; Lin, S.X.; Zhang, Y.Q.; Song, S.D.; Jiang, F.N.; Zhong, W.D.; et al. Expression of PD-L1 in tumor-associated nerves correlates with reduced CD8(+) tumor-associated lymphocytes and poor prognosis in prostate cancer. Int. J. Cancer 2019, 144, 3099-3110. [CrossRef]

55. Papanicolau-Sengos, A.; Yang, Y.; Pabla, S.; Lenzo, F.L.; Kato, S.; Kurzrock, R.; DePietro, P.; Nesline, M.; Conroy, J.; Glenn, S.; et al. Identification of targets for prostate cancer immunotherapy. Prostate 2019, 79, 498-505. [CrossRef] [PubMed]

56. Von Hardenberg, J.; Hartmann, S.; Nitschke, K.; Worst, T.S.; Ting, S.; Reis, H.; Nuhn, P.; Weis, C.A.; Erben, P. Programmed Death Ligand 1 (PD-L1) Status and Tumor-Infiltrating Lymphocytes in Hot Spots of Primary and Liver Metastases in Prostate Cancer With Neuroendocrine Differentiation. Clin. Genitourin. Cancer 2019, 17, 145-153.e5. [CrossRef] [PubMed]

57. Jin, X.; Ding, D.; Yan, Y.; Li, H.; Wang, B.; Ma, L.; Ye, Z.; Ma, T.; Wu, Q.; Rodrigues, D.N.; et al. Phosphorylated RB Promotes Cancer Immunity by Inhibiting NF-kB Activation and PD-L1 Expression. Mol. Cell 2019, 73, 22-35.e6. [CrossRef] [PubMed] 
58. Karzai, F.; VanderWeele, D.; Madan, R.A.; Owens, H.; Cordes, L.M.; Hankin, A.; Couvillon, A.; Nichols, E.; Bilusic, M.; Beshiri, M.L.; et al. Activity of durvalumab plus olaparib in metastatic castration-resistant prostate cancer in men with and without DNA damage repair mutations. J. Immunother. Cancer 2018, 6, 141. [CrossRef]

59. Richter, I.; Jirasek, T.; Havlickova, I.; Curcikova, R.; Samal, V.; Dvorak, J.; Bartos, J. The expression of PD-L1 in patients with castrate prostate cancer treated with enzalutamide. J. BUON Off. J. Balk. Union Oncol. 2018, 23, 1796-1802.

60. Xiong, W.; Deng, H.; Huang, C.; Zen, C.; Jian, C.; Ye, K.; Zhong, Z.; Zhao, X.; Zhu, L. MLL3 enhances the transcription of PD-L1 and regulates anti-tumor immunity. Biochim. Biophys. Acta. Mol. Basis Dis. 2019, 1865, 454-463. [CrossRef]

61. Hahn, E.; Liu, S.K.; Vesprini, D.; Xu, B.; Downes, M.R. Immune infiltrates and PD-L1 expression in treatment-naïve acinar prostatic adenocarcinoma: An exploratory analysis. J. Clin. Pathol. 2018, 71, 1023-1027. [CrossRef]

62. Redman, J.M.; Steinberg, S.M.; Gulley, J.L. Quick efficacy seeking trial (QuEST1): A novel combination immunotherapy study designed for rapid clinical signal assessment metastatic castration-resistant prostate cancer. J. Immunother. Cancer $2018,6,91$. [CrossRef]

63. Nava Rodrigues, D.; Rescigno, P.; Liu, D.; Yuan, W.; Carreira, S.; Lambros, M.B.; Seed, G.; Mateo, J.; Riisnaes, R.; Mullane, S.; et al. Immunogenomic analyses associate immunological alterations with mismatch repair defects in prostate cancer. J. Clin. Investig. 2018, 128, 4441-4453. [CrossRef] [PubMed]

64. Salvi, S.; Casadio, V.; Martignano, F.; Gurioli, G.; Tumedei, M.M.; Calistri, D.; Gunelli, R.; Costantini, M. Carcinosarcoma of the prostate: Case report with molecular and histological characterization. Int. J. Biol. Markers 2018, 33, 540-544. [CrossRef] [PubMed]

65. Wang, C.; Hahn, E.; Slodkowska, E.; Eskander, A.; Enepekides, D.; Higgins, K.; Vesprini, D.; Liu, S.K.; Downes, M.R.; Xu, B. Reproducibility of PD-L1 immunohistochemistry interpretation across various types of genitourinary and head/neck carcinomas, antibody clones, and tissue types. Hum. Pathol. 2018, 82, 131-139. [CrossRef]

66. Hansen, A.R.; Massard, C.; Ott, P.A.; Haas, N.B.; Lopez, J.S.; Ejadi, S.; Wallmark, J.M.; Keam, B.; Delord, J.P.; Aggarwal, R.; et al. Pembrolizumab for advanced prostate adenocarcinoma: Findings of the KEYNOTE-028 study. Ann. Oncol. Off. J. Eur. Soc. Med. Oncol. 2018, 29, 1807-1813. [CrossRef] [PubMed]

67. McNeel, D.G.; Eickhoff, J.C.; Wargowski, E.; Zahm, C.; Staab, M.J.; Straus, J.; Liu, G. Concurrent, but not sequential, PD-1 blockade with a DNA vaccine elicits anti-tumor responses in patients with metastatic, castration-resistant prostate cancer. Oncotarget 2018, 9, 25586-25596. [CrossRef] [PubMed]

68. Ishiba, T.; Hoffmann, A.C.; Usher, J.; Elshimali, Y.; Sturdevant, T.; Dang, M.; Jaimes, Y.; Tyagi, R.; Gonzales, R.; Grino, M.; et al. Frequencies and expression levels of programmed death ligand 1 (PD-L1) in circulating tumor RNA (ctRNA) in various cancer types. Biochem. Biophys. Res. Commun. 2018, 500, 621-625. [CrossRef]

69. Xu, L.J.; Ma, Q.; Zhu, J.; Li, J.; Xue, B.X.; Gao, J.; Sun, C.Y.; Zang, Y.C.; Zhou, Y.B.; Yang, D.R.; et al. Combined inhibition of JAK1,2/Stat3-PD-L1 signaling pathway suppresses the immune escape of castration-resistant prostate cancer to NK cells in hypoxia. Mol. Med. Rep. 2018, 17, 8111-8120. [CrossRef]

70. Haffner, M.C.; Guner, G.; Taheri, D.; Netto, G.J.; Palsgrove, D.N.; Zheng, Q.; Guedes, L.B.; Kim, K.; Tsai, H.; Esopi, D.M.; et al. Comprehensive Evaluation of Programmed Death-Ligand 1 Expression in Primary and Metastatic Prostate Cancer. Am. J. Pathol. 2018, 188, 1478-1485. [CrossRef]

71. Nagaputra, J.; Thike, A.A.; Koh, V. Loss of Androgen Receptor Accompained by Paucity of PD-L1 in Prostate Cancer is Associated with Clinical Relapse. USCAP 2018 Abstracts: Genitourinary Pathology (894-1126). Meeting Abstract: 1033. Mod. Pathol. 2018, 31, 323-403.

72. Tu, Y.N.; Tong, W.L.; Yavorski, J.M.; Blanck, G. Immunogenomics: A Negative Prostate Cancer Outcome Associated with TcR- $\gamma / \delta$ Recombinations. Cancer Microenviron. Off. J. Int. Cancer Microenviron. Soc. 2018, 11, 41-49. [CrossRef]

73. Tao, Z.; Xu, S.; Ruan, H.; Wang, T.; Song, W.; Qian, L.; Chen, K. MiR-195/-16 Family Enhances Radiotherapy via T Cell Activation in the Tumor Microenvironment by Blocking the PD-L1 Immune Checkpoint. Cell. Physiol. Biochem. Int. J. Exp. Cell. Physiol. Biochem. Pharmacol. 2018, 48, 801-814. [CrossRef] [PubMed]

74. Budczies, J.; Denkert, C.; Győrffy, B.; Schirmacher, P.; Stenzinger, A. Chromosome 9p copy number gains involving PD-L1 are associated with a specific proliferation and immune-modulating gene expression program active across major cancer types. $B M C$ Med. Genom. 2017, 10, 74. [CrossRef]

75. Fankhauser, C.D.; Schüffler, P.J.; Gillessen, S.; Omlin, A.; Rupp, N.J.; Rueschoff, J.H.; Hermanns, T.; Poyet, C.; Sulser, T.; Moch, H.; et al. Comprehensive immunohistochemical analysis of PD-L1 shows scarce expression in castration-resistant prostate cancer. Oncotarget 2018, 9, 10284-10293. [CrossRef]

76. Truillet, C.; Oh, H.L.J.; Yeo, S.P.; Lee, C.Y.; Huynh, L.T.; Wei, J.; Parker, M.F.L.; Blakely, C.; Sevillano, N.; Wang, Y.H.; et al. Imaging PD-L1 Expression with ImmunoPET. Bioconjugate Chem. 2018, 29, 96-103. [CrossRef]

77. Zhang, J.; Bu, X.; Wang, H.; Zhu, Y.; Geng, Y.; Nihira, N.T.; Tan, Y.; Ci, Y.; Wu, F.; Dai, X.; et al. Cyclin D-CDK4 kinase destabilizes PD-L1 via cullin 3-SPOP to control cancer immune surveillance. Nature 2018, 553, 91-95. [CrossRef]

78. Chen, Y.P.; Zhang, Y.; Lv, J.W.; Li, Y.Q.; Wang, Y.Q.; He, Q.M.; Yang, X.J.; Sun, Y.; Mao, Y.P.; Yun, J.P.; et al. Genomic Analysis of Tumor Microenvironment Immune Types across 14 Solid Cancer Types: Immunotherapeutic Implications. Theranostics 2017, 7, 3585-3594. [CrossRef] [PubMed]

79. Calagua, C.; Russo, J.; Sun, Y.; Schaefer, R.; Lis, R.; Zhang, Z.; Mahoney, K.; Bubley, G.J.; Loda, M.; Taplin, M.E.; et al. Expression of PD-L1 in Hormone-naïve and Treated Prostate Cancer Patients Receiving Neoadjuvant Abiraterone Acetate plus Prednisone and Leuprolide. Clin. Cancer Res. Off. J. Am. Assoc. Cancer Res. 2017, 23, 6812-6822. [CrossRef] 
80. Schott, D.S.; Pizon, M.; Pachmann, U.; Pachmann, K. Sensitive detection of PD-L1 expression on circulating epithelial tumor cells (CETCs) could be a potential biomarker to select patients for treatment with PD-1/PD-L1 inhibitors in early and metastatic solid tumors. Oncotarget 2017, 8, 72755-72772. [CrossRef]

81. Petitprez, F.; Fossati, N.; Vano, Y.; Freschi, M.; Becht, E.; Lucianò, R.; Calderaro, J.; Guédet, T.; Lacroix, L.; Rancoita, P.M.V.; et al. PD-L1 Expression and CD8(+) T-cell Infiltrate are Associated with Clinical Progression in Patients with Node-positive Prostate Cancer. Eur. Urol. Focus 2019, 5, 192-196. [CrossRef] [PubMed]

82. Li, G.; Ross, J.; Yang, X. Mismatch Repair (MMR) Deficiency and PD-L1 Expression in the Prostatic Ductal Adenocarcinoma. Abstracts from USCAP 2019: Genitourinary Pathology (including renal tumors) (776-992). Meeting Abstract: 893. Mod. Pathol. 2019, 32, 91 .

83. Ness, N.; Andersen, S.; Khanehkenari, M.R.; Nordbakken, C.V.; Valkov, A.; Paulsen, E.E.; Nordby, Y.; Bremnes, R.M.; Donnem, T.; Busund, L.T.; et al. The prognostic role of immune checkpoint markers programmed cell death protein 1 (PD-1) and programmed death ligand 1 (PD-L1) in a large, multicenter prostate cancer cohort. Oncotarget 2017, 8, 26789-26801. [CrossRef]

84. Baas, W.; Gershburg, S.; Dynda, D.; Delfino, K.; Robinson, K.; Nie, D.; Yearley, J.H.; Alanee, S. Immune Characterization of the Programmed Death Receptor Pathway in High Risk Prostate Cancer. Clin. Genitourin. Cancer 2017, 15, 577-581. [CrossRef] [PubMed]

85. Gao, J.; Ward, J.F.; Pettaway, C.A.; Shi, L.Z.; Subudhi, S.K.; Vence, L.M.; Zhao, H.; Chen, J.; Chen, H.; Efstathiou, E.; et al. VISTA is an inhibitory immune checkpoint that is increased after ipilimumab therapy in patients with prostate cancer. Nat. Med. 2017, 23, 551-555. [CrossRef]

86. Lu, X.; Horner, J.W.; Paul, E.; Shang, X.; Troncoso, P.; Deng, P.; Jiang, S.; Chang, Q.; Spring, D.J.; Sharma, P.; et al. Effective combinatorial immunotherapy for castration-resistant prostate cancer. Nature 2017, 543, 728-732. [CrossRef]

87. Tretiakova, M.; Fulton, R.; Kocherginsky, M. Comparison of 4 PD-L1 Antibodies in 560 Kidney, Bladder and Prostate Cancers. Abstracts from USCAP 2019: Genitourinary Pathology (including Renal tumors). Meeting Abstract: 1062. Mod. Pathol. 2017, 30, 210-271.

88. Najjar, S.N.; Kallakury, B.V.S.; Sheehan, C.E. Infrequent PD-L1 Protetin Expression and Gene Amplification in Prostatic Adenocarcinomas (PACs). Abstracts from USCAP 2019: Genitourinary Pathology (including Renal tumors). Meeting Abstract: 992. Mod. Pathol. 2017, 30, 246A.

89. Hashimoto, Y.; Imai, A.; Hatakeyama, S.; Yoneyama, T.; Koie, T.; Ohyama, C. PD-L1 over expression may predict disease aggressiveness in prostate cancer. Meeting Abstract: 291P. Ann. Oncol. 2016, 27, 91-92. [CrossRef]

90. Gevensleben, H.; Holmes, E.E.; Goltz, D.; Dietrich, J.; Sailer, V.; Ellinger, J.; Dietrich, D.; Kristiansen, G. PD-L1 promoter methylation is a prognostic biomarker for biochemical recurrence-free survival in prostate cancer patients following radical prostatectomy. Oncotarget 2016, 7, 79943-79955. [CrossRef] [PubMed]

91. Zhou, Q.Z.; Liu, C.D.; Yang, J.K.; Guo, W.B.; Zhou, J.H.; Bian, J. Changed percentage of myeloid-derived suppressor cells in the peripheral blood of prostate cancer patients and its clinical implication. Zhonghua Nan Ke Xue Natl. J. Androl. 2016, $22,963-967$.

92. Sharma, V.; Dong, H.; Kwon, E.; Karnes, R.J. Positive Pelvic Lymph Nodes in Prostate Cancer Harbor Immune Suppressor Cells To Impair Tumor-reactive T Cells. Eur. Urol. Focus 2018, 4, 75-79. [CrossRef]

93. Goltz, D.; Holmes, E.E.; Gevensleben, H.; Sailer, V.; Dietrich, J.; Jung, M.; Röhler, M.; Meller, S.; Ellinger, J.; Kristiansen, G.; et al. CXCL12 promoter methylation and PD-L1 expression as prognostic biomarkers in prostate cancer patients. Oncotarget 2016, 7 , 53309-53320. [CrossRef] [PubMed]

94. Graff, J.N.; Alumkal, J.J.; Drake, C.G.; Thomas, G.V.; Redmond, W.L.; Farhad, M.; Cetnar, J.P.; Ey, F.S.; Bergan, R.C.; Slottke, R.; et al. Early evidence of anti-PD-1 activity in enzalutamide-resistant prostate cancer. Oncotarget 2016, 7, 52810-52817. [CrossRef]

95. Satelli, A.; Batth, I.S.; Brownlee, Z.; Rojas, C.; Meng, Q.H.; Kopetz, S.; Li, S. Potential role of nuclear PD-L1 expression in cell-surface vimentin positive circulating tumor cells as a prognostic marker in cancer patients. Sci. Rep. 2016, 6, 28910. [CrossRef] [PubMed]

96. Massari, F.; Ciccarese, C.; Caliò, A.; Munari, E.; Cima, L.; Porcaro, A.B.; Novella, G.; Artibani, W.; Sava, T.; Eccher, A.; et al. Magnitude of PD-1, PD-L1 and T Lymphocyte Expression on Tissue from Castration-Resistant Prostate Adenocarcinoma: An Exploratory Analysis. Target. Oncol. 2016, 11, 345-351. [CrossRef]

97. Gevensleben, H.; Dietrich, D.; Golletz, C.; Steiner, S.; Jung, M.; Thiesler, T.; Majores, M.; Stein, J.; Uhl, B.; Müller, S.; et al. The Immune Checkpoint Regulator PD-L1 Is Highly Expressed in Aggressive Primary Prostate Cancer. Clin. Cancer Res. Off. J. Am. Assoc. Cancer Res. 2016, 22, 1969-1977. [CrossRef] [PubMed]

98. Martin, A.M.; Nirschl, T.R.; Nirschl, C.J.; Francica, B.J.; Kochel, C.M.; van Bokhoven, A.; Meeker, A.K.; Lucia, M.S.; Anders, R.A.; DeMarzo, A.M.; et al. Paucity of PD-L1 expression in prostate cancer: Innate and adaptive immune resistance. Prostate Cancer Prostatic Dis. 2015, 18, 325-332. [CrossRef]

99. Shalapour, S.; Font-Burgada, J.; Di Caro, G.; Zhong, Z.; Sanchez-Lopez, E.; Dhar, D.; Willimsky, G.; Ammirante, M.; Strasner, A.; Hansel, D.E.; et al. Immunosuppressive plasma cells impede T-cell-dependent immunogenic chemotherapy. Nature 2015, 521, 94-98. [CrossRef]

100. Bishop, J.L.; Sio, A.; Angeles, A.; Roberts, M.E.; Azad, A.A.; Chi, K.N.; Zoubeidi, A. PD-L1 is highly expressed in Enzalutamide resistant prostate cancer. Oncotarget 2015, 6, 234-242. [CrossRef] [PubMed] 
101. Spary, L.K.; Salimu, J.; Webber, J.P.; Clayton, A.; Mason, M.D.; Tabi, Z. Tumor stroma-derived factors skew monocyte to dendritic cell differentiation toward a suppressive CD14(+) PD-L1(+) phenotype in prostate cancer. Oncoimmunology 2014, 3, e955331. [CrossRef]

102. Taube, J.M. Unleashing the immune system: PD-1 and PD-Ls in the pre-treatment tumor microenvironment and correlation with response to PD-1/PD-L1 blockade. Oncoimmunology 2014, 3, e963413. [CrossRef]

103. Taube, J.M.; Klein, A.; Brahmer, J.R.; Xu, H.; Pan, X.; Kim, J.H.; Chen, L.; Pardoll, D.M.; Topalian, S.L.; Anders, R.A. Association of PD-1, PD-1 ligands, and other features of the tumor immune microenvironment with response to anti-PD-1 therapy. Clin. Cancer Res. Off. J. Am. Assoc. Cancer Res. 2014, 20, 5064-5074. [CrossRef]

104. Topalian, S.L.; Hodi, F.S.; Brahmer, J.R.; Gettinger, S.N.; Smith, D.C.; McDermott, D.F.; Powderly, J.D.; Carvajal, R.D.; Sosman, J.A.; Atkins, M.B.; et al. Safety, activity, and immune correlates of anti-PD-1 antibody in cancer. N. Engl. J. Med. 2012, 366, 2443-2454. [CrossRef] [PubMed]

105. Dulos, J.; Carven, G.J.; van Boxtel, S.J.; Evers, S.; Driessen-Engels, L.J.; Hobo, W.; Gorecka, M.A.; de Haan, A.F.; Mulders, P.; Punt, C.J.; et al. PD-1 blockade augments Th1 and Th17 and suppresses Th2 responses in peripheral blood from patients with prostate and advanced melanoma cancer. J. Immunother. 2012, 35, 169-178. [CrossRef]

106. Zhou, J.E.; Yu, J.; Wang, Y.; Wang, H.; Wang, J.; Wang, Y.; Yu, L.; Yan, Z. ShRNA-mediated silencing of PD-1 augments the efficacy of chimeric antigen receptor $\mathrm{T}$ cells on subcutaneous prostate and leukemia xenograft. Biomed. Pharmacother. Biomed. Pharmacother. 2021, 137, 111339. [CrossRef] [PubMed]

107. Wu, Y.; Xie, J.; Jin, X.; Lenchine, R.V.; Wang, X.; Fang, D.M.; Nassar, Z.D.; Butler, L.M.; Li, J.; Proud, C.G. eEF2K enhances expression of PD-L1 by promoting the translation of its mRNA. Biochem. J. 2020, 477, 4367-4381. [CrossRef]

108. Zhang, W.; Shi, X.; Chen, R.; Zhu, Y.; Peng, S.; Chang, Y.; Nian, X.; Xiao, G.; Fang, Z.; Li, Y.; et al. Novel Long Non-coding RNA IncAMPC Promotes Metastasis and Immunosuppression in Prostate Cancer by Stimulating LIF/LIFR Expression. Mol. Ther. J. Am. Soc. Gene Ther. 2020, 28, 2473-2487. [CrossRef]

109. Rennier, K.; Shin, W.J.; Krug, E.; Virdi, G.; Pachynski, R.K. Chemerin Reactivates PTEN and Suppresses PD-L1 in Tumor Cells via Modulation of a Novel CMKLR1-mediated Signaling Cascade. Clin. Cancer Res. Off. J. Am. Assoc. Cancer Res. 2020, 26, 5019-5035. [CrossRef] [PubMed]

110. Philippou, Y.; Sjoberg, H.T.; Murphy, E.; Alyacoubi, S.; Jones, K.I.; Gordon-Weeks, A.N.; Phyu, S.; Parkes, E.E.; Gillies, M.W.; Lamb, A.D.; et al. Impacts of combining anti-PD-L1 immunotherapy and radiotherapy on the tumour immune microenvironment in a murine prostate cancer model. Br. J. Cancer 2020, 123, 1089-1100. [CrossRef]

111. Wang, B.; Sun, L.; Yuan, Z.; Tao, Z. Wee1 kinase inhibitor AZD1775 potentiates CD8+ T cell-dependent antitumour activity via dendritic cell activation following a single high dose of irradiation. Med. Oncol. 2020, 37, 66. [CrossRef]

112. Papaevangelou, E.; Smolarek, D.; Smith, R.A.; Dasgupta, P.; Galustian, C. Targeting Prostate Cancer Using Intratumoral Cytotopically Modified Interleukin-15 Immunotherapy in a Syngeneic Murine Model. Immunol. Targets Ther. 2020, 9, 115-130. [CrossRef]

113. Wei, J.; Wang, Y.H.; Lee, C.Y.; Truillet, C.; Oh, D.Y.; Xu, Y.; Ruggero, D.; Flavell, R.R.; VanBrocklin, H.F.; Seo, Y.; et al. An Analysis of Isoclonal Antibody Formats Suggests a Role for Measuring PD-L1 with Low Molecular Weight PET Radiotracers. Mol. Imaging Biol. 2020, 22, 1553-1561. [CrossRef] [PubMed]

114. Ding, H.; Wang, Z.; Pascal Laura, E.; Chen, W.; Wang, Z.; Wang, Z. Ell2 deficiency upregulates pd-11 expression via jak2 signaling in prostate cancer cells. Meeting Abstract: MP51-12. J. Urol. 2020, 203 (Suppl. 4), e768.

115. Sun, Y.; Wei, Q.; Huang, J.; Yang, L. Methylation can regulate the expression of pd-11 in small cell prostate cancer. Meeting Abstract: MP16-12. J. Urol. 2020, 203 (Suppl. 4), e219-e220.

116. Liu, J.; He, D.; Cheng, L.; Huang, C.; Zhang, Y.; Rao, X.; Kong, Y.; Li, C.; Zhang, Z.; Liu, J.; et al. p300/CBP inhibition enhances the efficacy of programmed death-ligand 1 blockade treatment in prostate cancer. Oncogene 2020, 39, 3939-3951. [CrossRef] [PubMed]

117. Yamazaki, T.; Buqué, A.; Ames, T.D.; Galluzzi, L. PT-112 induces immunogenic cell death and synergizes with immune checkpoint blockers in mouse tumor models. Oncoimmunology 2020, 9, 1721810. [CrossRef] [PubMed]

118. Zhang, X.; Chen, H.; Li, G.; Zhou, X.; Shi, Y.; Zou, F.; Chen, Y.; Gao, J.; Yang, S.; Wu, S.; et al. Increased Tim-3 expression on TILs during treatment with the Anchored GM-CSF vaccine and anti-PD-1 antibodies is inversely correlated with response in prostate cancer. J. Cancer 2020, 11, 648-656. [CrossRef]

119. Wang, B.; Zhou, Y.; Zhang, J.; Jin, X.; Wu, H.; Huang, H. Fructose-1,6-bisphosphatase loss modulates STAT3-dependent expression of PD-L1 and cancer immunity. Theranostics 2020, 10, 1033-1045. [CrossRef]

120. Orme, J.J.; Jazieh, K.A.; Xie, T.; Harrington, S.; Liu, X.; Ball, M.; Madden, B.; Charlesworth, M.C.; Azam, T.U.; Lucien, F.; et al. ADAM10 and ADAM17 cleave PD-L1 to mediate PD-(L)1 inhibitor resistance. Oncoimmunology 2020, 9, 1744980. [CrossRef] [PubMed]

121. Gan, S.; Ye, J.; Li, J.; Hu, C.; Wang, J.; Xu, D.; Pan, X.; Chu, C.; Chu, J.; Zhang, J.; et al. LRP11 activates $\beta$-catenin to induce PD-L1 expression in prostate cancer. J. Drug Target. 2020, 28, 508-515. [CrossRef]

122. Choi, B.; Jung, H.; Yu, B.; Choi, H.; Lee, J.; Kim, D.H. Sequential MR Image-Guided Local Immune Checkpoint Blockade Cancer Immunotherapy Using Ferumoxytol Capped Ultralarge Pore Mesoporous Silica Carriers after Standard Chemotherapy. Small 2019, 15, e1904378. [CrossRef] [PubMed] 
123. Mao, W.; Ghasemzadeh, A.; Freeman, Z.T.; Obradovic, A.; Chaimowitz, M.G.; Nirschl, T.R.; McKiernan, E.; Yegnasubramanian, S.; Drake, C.G. Immunogenicity of prostate cancer is augmented by BET bromodomain inhibition. J. Immunother. Cancer $2019,7,277$. [CrossRef]

124. Zhou, Q.; Xiong, W.; Zhou, X.; Gao, R.S.; Lin, Q.F.; Liu, H.Y.; Li, J.N.; Tian, X.F. CTHRC1 and PD-1/PD-L1 expression predicts tumor recurrence in prostate cancer. Mol. Med. Rep. 2019, 20, 4244-4252. [CrossRef]

125. Xu, Q.; Long, Q.; Zhu, D.; Fu, D.; Zhang, B.; Han, L.; Qian, M.; Guo, J.; Xu, J.; Cao, L.; et al. Targeting amphiregulin (AREG) derived from senescent stromal cells diminishes cancer resistance and averts programmed cell death 1 ligand (PD-L1)-mediated immunosuppression. Aging Cell 2019, 18, e13027. [CrossRef] [PubMed]

126. Dudzinski, S.O.; Cameron, B.D.; Wang, J.; Rathmell, J.C.; Giorgio, T.D.; Kirschner, A.N. Combination immunotherapy and radiotherapy causes an abscopal treatment response in a mouse model of castration resistant prostate cancer. J. Immunother. Cancer 2019, 7, 218. [CrossRef]

127. Li, X.; Wang, Z.; Huang, J.; Luo, H.; Zhu, S.; Yi, H.; Zheng, L.; Hu, B.; Yu, L.; Li, L.; et al. Specific zinc finger-induced methylation of PD-L1 promoter inhibits its expression. FEBS Open Biol. 2019, 9, 1063-1070. [CrossRef]

128. Liu, K.; Zhou, Z.; Gao, H.; Yang, F.; Qian, Y.; Jin, H.; Guo, Y.; Liu, Y.; Li, H.; Zhang, C.; et al. JQ1, a BET-bromodomain inhibitor, inhibits human cancer growth and suppresses PD-L1 expression. Cell Biol. Int. 2019, 43, 642-650. [CrossRef]

129. Xu, N.; Huang, L.; Li, X.; Watanabe, M.; Li, C.; Xu, A.; Liu, C.; Li, Q.; Araki, M.; Wada, K.; et al. The Novel Combination of Nitroxoline and PD-1 Blockade, Exerts a Potent Antitumor Effect in a Mouse Model of Prostate Cancer. Int. J. Biol. Sci. 2019, 15, 919-928. [CrossRef]

130. Yoneda, T.; Kunimura, N.; Kitagawa, K.; Fukui, Y.; Saito, H.; Narikiyo, K.; Ishiko, M.; Otsuki, N.; Nibu, K.I.; Fujisawa, M.; et al. Overexpression of SOCS3 mediated by adenovirus vector in mouse and human castration-resistant prostate cancer cells increases the sensitivity to NK cells in vitro and in vivo. Cancer Gene Ther. 2019, 26, 388-399. [CrossRef] [PubMed]

131. Fenerty, K.E.; Padget, M.; Wolfson, B.; Gameiro, S.R.; Su, Z.; Lee, J.H.; Rabizadeh, S.; Soon-Shiong, P.; Hodge, J.W. Immunotherapy utilizing the combination of natural killer- and antibody dependent cellular cytotoxicity (ADCC)-mediating agents with poly (ADP-ribose) polymerase (PARP) inhibition. J. Immunother. Cancer 2018, 6, 133. [CrossRef] [PubMed]

132. Krueger, T.E.; Thorek, D.L.J.; Meeker, A.K.; Isaacs, J.T.; Brennen, W.N. Tumor-infiltrating mesenchymal stem cells: Drivers of the immunosuppressive tumor microenvironment in prostate cancer? Prostate 2019, 79, 320-330. [CrossRef]

133. Medina, E.M.M.; Félix, A.J.; Ciudad, C.J.; Noé, V. Cancer immunotherapy using PolyPurine Reverse Hoogsteen hairpins targeting the PD-1/PD-L1 pathway in human tumor cells. PLoS ONE 2018, 13, e0206818.

134. Moreira, D.; Adamus, T.; Zhao, X.; Su, Y.L.; Zhang, Z.; White, S.V.; Swiderski, P.; Lu, X.; DePinho, R.A.; Pal, S.K.; et al STAT3 Inhibition Combined with CpG Immunostimulation Activates Antitumor Immunity to Eradicate Genetically Distinct Castration-Resistant Prostate Cancers. Clin. Cancer Res. Off. J. Am. Assoc. Cancer Res. 2018, 24, 5948-5962. [CrossRef]

135. Zhang, L.; Xu, L.J.; Zhu, J.; Li, J.; Xue, B.X.; Gao, J.; Sun, C.Y.; Zang, Y.C.; Zhou, Y.B.; Yang, D.R.; et al. ATM-JAK-PD-L1 signaling pathway inhibition decreases EMT and metastasis of androgen-independent prostate cancer. Mol. Med. Rep. 2018, 17, 7045-7054 [CrossRef] [PubMed]

136. Yin, C.; Wang, Y.; Ji, J.; Cai, B.; Chen, H.; Yang, Z.; Wang, K.; Luo, C.; Zhang, W.; Yuan, C.; et al. Molecular Profiling of Pooled Circulating Tumor Cells from Prostate Cancer Patients Using a Dual-Antibody-Functionalized Microfluidic Device. Anal. Chem. 2018, 90, 3744-3751. [CrossRef]

137. Ahern, E.; Harjunpää, H.; O’Donnell, J.S.; Allen, S.; Dougall, W.C.; Teng, M.W.L.; Smyth, M.J. RANKL blockade improves efficacy of PD1-PD-L1 blockade or dual PD1-PD-L1 and CTLA4 blockade in mouse models of cancer. Oncoimmunology 2018, 7, e1431088. [CrossRef] [PubMed]

138. Xu, L.; Shen, M.; Chen, X.; Yang, D.R.; Tsai, Y.; Keng, P.C.; Lee, S.O.; Chen, Y. In vitro-induced M2 type macrophages induces the resistance of prostate cancer cells to cytotoxic action of NK cells. Exp. Cell Res. 2018, 364, 113-123. [CrossRef]

139. Xu, L.; Chen, X.; Shen, M.; Yang, D.R.; Fang, L.; Weng, G.; Tsai, Y.; Keng, P.C.; Chen, Y.; Lee, S.O. Inhibition of IL-6-JAK/Stat3 signaling in castration-resistant prostate cancer cells enhances the NK cell-mediated cytotoxicity via alteration of PD-L1/NKG2D ligand levels. Mol. Oncol. 2018, 12, 269-286. [CrossRef]

140. Xu, L.; Shen, M.; Chen, X.; Zhu, R.; Yang, D.R.; Tsai, Y.; Keng, P.C.; Chen, Y.; Lee, S.O. Adipocytes affect castration-resistant prostate cancer cells to develop the resistance to cytotoxic action of NK cells with alterations of PD-L1/NKG2D ligand levels in tumor cells. Prostate 2018, 78, 353-364. [CrossRef]

141. Zhang, Y.; Zhu, S.; Qian, P.; Wang, X.; Xu, Z.; Sun, W.; Xu, Y. RelB upregulates PD-L1 in advanced prostate cancer: An insight into tumor immunoescape. Meeting Abstract 2791. Cancer Res. 2019, 79 (Suppl. 13), 2791.

142. Shimizu, N.; Velasco, M.A.D.; Kura, Y. PD-L1 immune checkpoint blockade in genetically engineered mouse models of prostate cancer. Abstracts of the 76th Annual Meeting of the Japanese Cancer Association; Yokohama, Japan, 28-30 September 2017. Meeting Abstract: P-1246. Cancer Sci. 2018, 109, 292.

143. Maher, C.M.; Thomas, J.D.; Haas, D.A.; Longen, C.G.; Oyer, H.M.; Tong, J.Y.; Kim, F.J. Small-Molecule Sigma1 Modulator Induces Autophagic Degradation of PD-L1. Mol. Cancer Res. MCR 2018, 16, 243-255. [CrossRef] [PubMed]

144. Shi, X.; Zhang, X.; Li, J.; Zhao, H.; Mo, L.; Shi, X.; Hu, Z.; Gao, J.; Tan, W. PD-1/PD-L1 blockade enhances the efficacy of SA-GM-CSF surface-modified tumor vaccine in prostate cancer. Cancer Lett. 2017, 406, 27-35. [CrossRef] [PubMed]

145. Cappuccini, F.; Pollock, E.; Stribbling, S.; Hill, A.V.S.; Redchenko, I. 5T4 oncofoetal glycoprotein: An old target for a novel prostate cancer immunotherapy. Oncotarget 2017, 8, 47474-47489. [CrossRef] 
146. De Velasco, M.A.; Kura, Y.; Ando, N.; Sato, N.; Sakai, K.; Davies, B.R.; Sugimoto, K.; Nozawa, M.; Yoshimura, K.; Yoshikawa, K.; et al. PD-L1 blockade in preclinical models of PTEN-deficient prostate cancer. Meeting Abstract: 4702. Cancer Res. 2017, 77 (Suppl. 13), 4702.

147. Liu, Z.; Zhao, Y.; Fang, J.; Cui, R.; Xiao, Y.; Xu, Q. SHP2 negatively regulates HLA-ABC and PD-L1 expression via STAT1 phosphorylation in prostate cancer cells. Oncotarget 2017, 8, 53518-53530. [CrossRef] [PubMed]

148. Tanoue, K.; Rosewell Shaw, A.; Watanabe, N.; Porter, C.; Rana, B.; Gottschalk, S.; Brenner, M.; Suzuki, M. Armed Oncolytic Adenovirus-Expressing PD-L1 Mini-Body Enhances Antitumor Effects of Chimeric Antigen Receptor T Cells in Solid Tumors. Cancer Res. 2017, 77, 2040-2051. [CrossRef]

149. Wang, X.; Yang, L.; Huang, F.; Zhang, Q.; Liu, S.; Ma, L.; You, Z. Inflammatory cytokines IL-17 and TNF- $\alpha$ up-regulate PD-L1 expression in human prostate and colon cancer cells. Immunol. Lett. 2017, 184, 7-14. [CrossRef] [PubMed]

150. Serganova, I.; Moroz, E.; Cohen, I.; Moroz, M.; Mane, M.; Zurita, J.; Shenker, L.; Ponomarev, V.; Blasberg, R. Enhancement of PSMA-Directed CAR Adoptive Immunotherapy by PD-1/PD-L1 Blockade. Mol. Ther. Oncolytics 2017, 4, 41-54. [CrossRef]

151. Rekoske, B.T.; Olson, B.M.; McNeel, D.G. Antitumor vaccination of prostate cancer patients elicits PD-1/PD-L1 regulated antigen-specific immune responses. Oncoimmunology 2016, 5, e1165377. [CrossRef]

152. Rekoske, B.T.; Smith, H.A.; Olson, B.M.; Maricque, B.B.; McNeel, D.G. PD-1 or PD-L1 Blockade Restores Antitumor Efficacy Following SSX2 Epitope-Modified DNA Vaccine Immunization. Cancer Immunol. Res. 2015, 3, 946-955. [CrossRef]

153. Black, M.; Barsoum, I.B.; Truesdell, P.; Cotechini, T.; Macdonald-Goodfellow, S.K.; Petroff, M.; Siemens, D.R.; Koti, M.; Craig, A.W.; Graham, C.H. Activation of the PD-1/PD-L1 immune checkpoint confers tumor cell chemoresistance associated with increased metastasis. Oncotarget 2016, 7, 10557-10567. [CrossRef]

154. Yang, S.; Zhang, Q.; Liu, S.; Wang, A.R.; You, Z. PD-1, PD-L1 and PD-L2 expression in mouse prostate cancer. Am. J. Clin. Exp. Urol. 2016, 4, 1-8. [PubMed]

155. Carbotti, G.; Barisione, G.; Airoldi, I.; Mezzanzanica, D.; Bagnoli, M.; Ferrero, S.; Petretto, A.; Fabbi, M.; Ferrini, S. IL-27 induces the expression of IDO and PD-L1 in human cancer cells. Oncotarget 2015, 6, 43267-43280. [CrossRef] [PubMed]

156. Bernstein, M.B.; Garnett, C.T.; Zhang, H.; Velcich, A.; Wattenberg, M.M.; Gameiro, S.R.; Kalnicki, S.; Hodge, J.W.; Guha, C. Radiation-induced modulation of costimulatory and coinhibitory T-cell signaling molecules on human prostate carcinoma cells promotes productive antitumor immune interactions. Cancer Biother. Radiopharm. 2014, 29, 153-161. [CrossRef]

157. Yu, P.; Steel, J.C.; Zhang, M.; Morris, J.C.; Waitz, R.; Fasso, M.; Allison, J.P.; Waldmann, T.A. Simultaneous inhibition of two regulatory T-cell subsets enhanced Interleukin-15 efficacy in a prostate tumor model. Proc. Natl. Acad. Sci. USA 2012, 109, 6187-6192. [CrossRef]

158. Lin, H.; Liu, Q.; Zeng, X.; Yu, W.; Xu, G. Pembrolizumab with or without enzalutamide in selected populations of men with previously untreated metastatic castration-resistant prostate cancer harbouring programmed cell death ligand-1 staining: A retrospective study. BMC Cancer 2021, 21, 399. [CrossRef]

159. Morel, K.L.; Sheahan, A.V.; Burkhart, D.L.; Baca, S.C.; Boufaied, N.; Liu, Y.; Qiu, X.; Cañadas, I.; Roehle, K.; Heckler, M.; et al EZH2 inhibition activates a dsRNA-STING-interferon stress axis that potentiates response to PD-1 checkpoint blockade in prostate cancer. Nat. Cancer 2021, 2, 444-456. [CrossRef] [PubMed]

160. Cha, J.H.; Chan, L.C.; Li, C.W.; Hsu, J.L.; Hung, M.C. Mechanisms Controlling PD-L1 Expression in Cancer. Mol. Cell 2019, 76, 359-370. [CrossRef] [PubMed]

161. Saramaki, O.; Visakorpi, T. Chromosomal aberrations in prostate cancer. Front. Biosci 2007, 12, 3287-3301. [CrossRef] [PubMed]

162. Von Knobloch, R.; Konrad, L.; Barth, P.J.; Brandt, H.; Wille, S.; Heidenreich, A.; Moll, R.; Hofmann, R. Genetic pathways and new progression markers for prostate cancer suggested by microsatellite allelotyping. Clin. Cancer Res. 2004, 10, 1064-1073. [CrossRef]

163. Nielsen, T.; Wallden, B.; Schaper, C.; Ferree, S.; Liu, S.; Gao, D.; Barry, G.; Dowidar, N.; Maysuria, M.; Storhoff, J. Analytical validation of the PAM50-based Prosigna Breast Cancer Prognostic Gene Signature Assay and nCounter Analysis System using formalin-fixed paraffin-embedded breast tumor specimens. BMC Cancer 2014, 14, 177. [CrossRef]

164. Gandhi, J.; Afridi, A.; Vatsia, S.; Joshi, G.; Joshi, G.; Kaplan, S.A.; Smith, N.L.; Khan, S.A. The molecular biology of prostate cancer: Current understanding and clinical implications. Prostate Cancer Prostatic Dis. 2018, 21, 22-36. [CrossRef]

165. Schroder, K.; Hertzog, P.J.; Ravasi, T.; Hume, D.A. Interferon-gamma: An overview of signals, mechanisms and functions. J. Leukoc. Biol. 2004, 75, 163-189. [CrossRef]

166. Dunn, G.P.; Sheehan, K.C.F.; Old, L.J.; Schreiber, R.D. IFN unresponsiveness in LNCaP cells due to the lack of JAK1 gene expression. Cancer Res. 2005, 65, 3447. [CrossRef] [PubMed]

167. Angell, T.E.; Lechner, M.G.; Jang, J.K.; LoPresti, J.S.; Epstein, A.L. MHC class I loss is a frequent mechanism of immune escape in papillary thyroid cancer that is reversed by interferon and selumetinib treatment in vitro. Clin. Cancer Res. 2014, 20,6034-6044. [CrossRef] [PubMed]

168. Yarchoan, M.; Hopkins, A.; Jaffee, E.M. Tumor Mutational Burden and Response Rate to PD-1 Inhibition. N. Engl. J. Med. 2017, 377, 2500-2501. [CrossRef]

169. Flammiger, A.; Weisbach, L.; Huland, H.; Tennstedt, P.; Simon, R.; Minner, S.; Bokemeyer, C.; Sauter, G.; Schlomm, T.; Trepel, M. High tissue density of FOXP3+ T cells is associated with clinical outcome in prostate cancer. Eur. J. Cancer 2013, 49, 1273-1279. [CrossRef]

170. Lopez-Bujanda, Z.; Drake, C.G. Myeloid-derived cells in prostate cancer progression: Phenotype and prospective therapies. J. Leukoc. Biol. 2017, 102, 393-406. [CrossRef] [PubMed] 
171. Holohan, C.; Van Schaeybroeck, S.; Longley, D.B.; Johnston, P.G. Cancer drug resistance: An evolving paradigm. Nat. Rev. Cancer 2013, 13, 714-726. [CrossRef]

172. Dorand, R.D.; Nthale, J.; Myers, J.T.; Barkauskas, D.S.; Avril, S.; Chirieleison, S.M.; Pareek, T.K.; Abbott, D.W.; Stearns, D.S.; Letterio, J.J.; et al. Cdk5 disruption attenuates tumor PD-L1 expression and promotes antitumor immunity. Science 2016, 353, 399-403. [CrossRef]

173. Lee, C.; Zhang, Q.; Zi, X.; Dash, A.; Soares, M.B.; Rahmatpanah, F.; Jia, Z.; McClelland, M.; Mercola, D. TGF- $\beta$ mediated DNA methylation in prostate cancer. Transl. Androl. Urol. 2012, 1, 78-88.

174. Sfanos, K.S.; Bruno, T.C.; Maris, C.H.; Xu, L.; Thoburn, C.J.; DeMarzo, A.M.; Meeker, A.K.; Isaacs, W.B.; Drake, C.G. Phenotypic analysis of prostate-infiltrating lymphocytes reveals TH17 and Treg skewing. Clin. Cancer Res. 2008, 14, 3254-3261. [CrossRef] [PubMed]

175. Hirahara, K.; Ghoreschi, K.; Yang, X.P.; Takahashi, H.; Laurence, A.; Vahedi, G.; Sciumè, G.; Hall, A.O.; Dupont, C.D.; Francisco, L.M.; et al. Interleukin-27 priming of T cells controls IL-17 production in trans via induction of the ligand PDL1. Immunity 2012, 36, 1017-1030. [CrossRef] [PubMed]

176. Jovasevic, V.M.; Gorelik, L.; Bluestone, J.A.; Mokyr, M.B. Importance of IL-10 for CTLA-4-mediated inhibition of tumor-eradicating immunity. J. Immunol. 2004, 172, 1449-1454. [CrossRef]

177. Packer, J.R.; Maitland, N.J. The molecular and cellular origin of human prostate cancer. Biochim. Biophys. Acta 2016, 1863 Pt 6, 1238-1260. [CrossRef] [PubMed]

178. Hobisch, A.; Eder, I.E.; Putz, T.; Horninger, W.; Bartsch, G.; Klocker, H.; Culig, Z. Interleukin-6 regulates prostate-specific protein expression in prostate carcinoma cells by activation of the androgen receptor. Cancer Res. 1998, 58, 4640-4645.

179. Demaria, M.; O'Leary, M.N.; Chang, J.; Shao, L.; Liu, S.; Alimirah, F.; Koenig, K.; Le, C.; Mitin, N.; Deal, A.M.; et al. Cellular senescence promotes adverse effects of chemotherapy and cancer relapse. Cancer Discov. 2017, 7, 165-176. [CrossRef]

180. Xu, Q.; Chiao, P.; Sun, Y. Amphiregulin in Cancer: New Insights for Translational Medicine. Trends Cancer 2016, 2, 111-113. [CrossRef]

181. Zaiss, D.M.; van Loosdregt, J.; Gorlani, A.; Bekker, C.P.; Gröne, A.; Sibilia, M.; van Bergen en Henegouwen, P.M.; Roovers, R.C.; Coffer, P.J.; Sijts, A.J. Amphiregulin enhances regulatory T cell-suppressive function via the epidermal growth factor receptor. Immunity 2013, 38, 275-284. [CrossRef]

182. Bai, R.; Chen, N.; Li, L.; Du, N.; Bai, L.; Lv, Z.; Tian, H.; Cui, J. Mechanisms of cancers resistance to immunotherapy. Front. Oncol. 2020, 10, 1290. [CrossRef] [PubMed]

183. Crane, C.A.; Panner, A.; Murray, J.C.; Wilson, S.P.; Xu, H.; Chen, L.; Simko, J.P.; Waldman, F.M.; Pieper, R.O.; Parsa, A.T. PI(3) kinase is associated with a mechanism of immunoresistance in breast and prostate cancer. Oncogene 2009, 28, 306-312. [CrossRef] [PubMed]

184. Mercader, M.; Bodner, B.K.; Moser, M.T.; Kwon, P.S.; Park, E.S.; Manecke, R.G.; Ellis, T.M.; Wojcik, E.M.; Yang, D.; Flanigan, R.C.; et al. T cell infiltration of the prostate induced by androgen withdrawal in patients with prostate cancer. Proc. Natl. Acad. Sci. USA 2001, 98, 14565-14570. [CrossRef]

185. Bansal, D.; Reimers, M.A.; Knoche, E.M.; Pachynski, R.K. Immunotherapy and Immunotherapy Combinations in Metastatic Castration-Resistant Prostate Cancer. Cancers 2021, 13, 334. [CrossRef] [PubMed]

186. Owen, K.L.; Gearing, L.J.; Zanker, D.J.; Brockwell, N.K.; Khoo, W.H.; Roden, D.L.; Cmero, M.; Mangiola, S.; Hong, M.K.; Spurling, A.J.; et al. Prostate cancer cell-intrinsic interferon signaling regulates dormancy and metastatic outgrowth in bone. EMBO Rep. 2020, 21, e50162. [CrossRef]

187. Bard-Chapeau, E.A.; Li, S.; Ding, J.; Zhang, S.S.; Zhu, H.H.; Princen, F.; Fang, D.D.; Han, T.; Bailly-Maitre, B.; Poli, V.; et al. Ptpn11/Shp2 acts as a tumor suppressor in hepatocellular carcinogenesis. Cancer Cell 2011, 19, 629-639. [CrossRef]

188. Lindholm, P.F.; Lu, Y.; Adley, B.P.; Vladislav, T.; Jovanovic, B.; Sivapurapu, N.; Yang, X.J.; Kajdacsy-Balla, A. Role of monocytelineage cells in prostate cancer cell invasion and tissue factor expression. Prostate 2010, 70, 1672-1682. [CrossRef]

189. Peng, Y.; Dong, S.; Yang, Z.; Song, Y.; Ding, J.; Hou, D.; Wang, L.; Zhang, Z.; Li, N.; Wang, H. Identification of docetaxel-related biomarkers for prostate cancer. Andrologia 2021, 53, e14079. [CrossRef]

190. Pasero, C.; Gravis, G.; Granjeaud, S.; Guerin, M.; Thomassin- Piana, J.; Rocchi, P.; Salem, N.; Walz, J.; Moretta, A.; Olive, D. Highly effective NK cells are associated with good prognosis in patients with metastatic prostate cancer. Oncotarget 2015, 6, 14360-14373. [CrossRef]

191. Abe, K.; Harada, M.; Tamada, K.; Ito, O.; Li, T.; Nomoto, K. Early-appearing tumor-infiltrating natural killer cells play an important role in the nitric oxide production of tumor-associated macrophages through their interferon production. Cancer Immunol. Immunother. 1998, 45, 225-233. [CrossRef]

192. Nausch, N.; Cerwenka, A. NKG2D ligands in tumor immunity. Oncogene 2008, 27, 5944-5958. [CrossRef]

193. Joo, H.Y.; Yun, M.; Jeong, J.; Park, E.R.; Shin, H.J.; Woo, S.R.; Jung, J.K.; Kim, Y.M.; Park, J.J.; Kim, J.; et al. SIRT1 deacetylates and stabilizes hypoxia-inducible factor- $1 \alpha(\mathrm{HIF}-1 \alpha)$ via direct inter- actions during hypoxia. Biochem. Biophys. Res. Commun. 2015, 462, 294-300. [CrossRef]

194. Won, H.; Moreira, D.; Gao, C.; Duttagupta, P.; Zhao, X.; Manuel, E.; Diamond, D.; Yuan, Y.C.; Liu, Z.; Jones, J.; et al. TLR9 expression and secretion of LIF by prostate cancer cells stimulates accu- mulation and activity of polymorphonuclear MDSCs. J. Leukoc. Biol. 2017, 102, 423-436. [CrossRef] 
195. Calcinotto, A.; Spataro, C.; Zagato, E.; Di Mitri, D.; Gil, V.; Crespo, M.; Bernardis, G.; Losa, M.; Mirenda, M.; Pasquini, E.; et al. IL-23 secreted by myeloid cells drives castration-resistant prostate cancer. Nature 2018, 559, 363-369. [CrossRef]

196. Zhang, Q.; Sun, L.J.; Qi, J.; Yang, Z.G.; Huang, T.; Huo, R.C. Periprostatic adiposity measured on magnetic resonance imaging correlates with prostate cancer aggressiveness. Urol. J. 2014, 11, 1793-1799. [PubMed]

197. Freedland, A.R.; Freedland, S.J. Among active Ssurveillance candidates does obesity influence tumor aggressiveness and/or location? J. Urol. 2017, 198, 4-5. [CrossRef]

198. Fried, S.K.; Bunkin, D.A.; Greenberg, A.S. Omental and subcutaneous adipose tissues of obese subjects release interleukin-6: Depot difference and regulation by glucocorticoid. J. Clin. Endocrinoland Metab. 1998, 83, 847-850. [CrossRef]

199. Sato, H.; Niimi, A.; Yasuhara, T.; Permata, T.; Hagiwara, Y.; Isono, M.; Nuryadi, E.; Sekine, R.; Oike, T.; Kakoti, S.; et al. DNA double-strand break repair pathway regulates PD-L1 expression in cancer cells. Nat. Commun. 2017, 8, 1751. [CrossRef] [PubMed]

200. Ding, L.W.; Sun, Q.Y.; Edwards, J.J.; Fernández, L.T.; Ran, X.B.; Zhou, S.Q.; Scolyer, R.A.; Wilmott, J.S.; Thompson, J.F.; Doan, N.; et al. LNK suppresses interferon signaling in melanoma. Nat. Commun 2019, 10, 2230. [CrossRef]

201. Manguso, R.T.; Pope, H.W.; Zimmer, M.D.; Brown, F.D.; Yates, K.B.; Miller, B.C.; Collins, N.B.; Bi, K.; LaFleur, M.W.; Juneja, V.R.; et al. In vivo CRISPR screening identifies Ptpn2 as a cancer immunotherapy target. Nature 2017, 547, 413-418. [CrossRef] [PubMed]

202. Zaretsky, J.M.; Garcia-Diaz, A.; Shin, D.S.; Escuin-Ordinas, H.; Hugo, W.; Hu-Lieskovan, S.; Torrejon, D.Y.; Abril-Rodriguez, G.; Sandoval, S.; Barthly, L.; et al. Mutations Associated with Acquired Resistance to PD-1 Blockade in Melanoma. N. Engl. J. Med. 2016, 375, 819-829. [CrossRef]

203. Tam, L.; McGlynn, L.M.; Traynor, P.; Mukherjee, R.; Bartlett, J.M.S.; Edwards, J. Expression levels of the JAK/STAT pathway in the transition from hormone-sensitive to hormone-refractory prostate cancer. Br. J. Cancer 2007, 97, 378. [CrossRef] [PubMed]

204. Sun, L.L.; Yang, R.Y.; Li, C.W.; Chen, M.K.; Shao, B.; Hsu, J.M.; Chan, L.C.; Yang, Y.; Hsu, J.L.; Lai, Y.J.; et al. Inhibition of ATR downregulates PD-L1 and sensitizes tumor cells to T cell-mediated killing. Am. J. Cancer Res. 2018, 8, 1307-1316.

205. Barton, B.E.; Karras, J.G.; Murphy, T.F.; Barton, A.; Huang, H.F. Signal transducer and activator of transcription 3 (STAT3) activation in prostate cancer: Direct STAT3 inhibition induces apoptosis in prostate cancer lines. Mol. Cancer Ther. 2004, 3, 11-20.

206. Yu, H.; Lee, H.; Herrmann, A.; Buettner, R.; Jove, R. Revisiting STAT3 signalling in cancer: New and unexpected biological functions. Nat. Rev. Cancer 2014, 14, 736-746. [CrossRef]

207. Heinrich, P.C.; Behrmann, I.; Haan, S.; Hermanns, H.M.; Müller-Newen, G.; Schaper, F. Principles of interleukin (IL)-6-type cytokine sig- nalling and its regulation. Biochem. J. 2003, 374, 1-20. [CrossRef] [PubMed]

208. Don-Doncow, N.; Marginean, F.; Coleman, I.; Nelson, P.S.; Ehrnström, R.; Krzyzanowska, A.; Morrissey, C.; Hellsten, R.; Bjartell, A. Expression of STAT3 in Prostate Cancer Metastases. Eur. Urol. 2017, 71, 313-316. [CrossRef] [PubMed]

209. Kroon, P.; Berry, P.A.; Stower, M.J.; Rodrigues, G.; Mann, V.M.; Simms, M.; Bhasin, D.; Chettiar, S.; Li, C.; Li, P.K.; et al. JAK-STAT blockade inhibits tumor initiation and clonogenic recovery of prostate cancer stem-like cells. Cancer Res. 2013, 73, 5288-5298. [CrossRef]

210. Huang, S.; Liu, Q.; Liao, Q.; Wu, Q.; Sun, B.; Yang, Z.; Hu, X.; Tan, M.; Li, L. Interleukin- 6/signal transducer and activator of transcription 3 promotes prostate cancer resistance to androgen deprivation therapy via regulating pituitary tumor transforming gene 1 expression. Cancer Sci. 2018, 109, 678-687. [CrossRef]

211. Junttila, M.R.; Li, S.P.; Westermarck, J. Phosphatase-mediated crosstalk between MAPK signaling pathways in the regulation of cell survival. FASEB J. 2008, 22, 954-965. [CrossRef]

212. Royuela, M.; Arenas, M.I.; Bethencourt, F.R.; Sánchez-Chapado, M.; Fraile, B.; Paniagua, R. Regulation of proliferation/apoptosis equilibrium by mitogen-activated protein kinases in normal, hyperplastic, and carcinomatous human prostate. Hum. Pathol. 2002, 33, 299-306. [CrossRef]

213. Meshki, J.; Caino, M.C.; von Burstin, V.A.; Griner, E.; Kazanietz, M.G. Regulation of prostate cancer cell survival by protein kinase Cepsilon involves bad phosphorylation and modulation of the TNFalpha/JNK pathway. J. Biol. Chem. 2010, 285, 26033-26040. [CrossRef] [PubMed]

214. Xu, R.; Hu, J. The role of JNK in prostate cancer progression and therapeutic strategies. Biomed. Pharmacother. 2020, 121, 109679. [CrossRef]

215. Mulholland, D.J.; Kobayashi, N.; Ruscetti, M.; Zhi, A.; Tran, L.M.; Huang, J.; Gleave, M.; Wu, H. Pten loss and RAS/MAPK activation cooperate to promote EMT and metastasis initiated from prostate cancer stem/progenitor cells. Cancer Res. 2012, 72 , 1878-1889. [CrossRef]

216. Nickols, N.G.; Nazarian, R.; Zhao, S.G.; Tan, V.; Uzunangelov, V.; Xia, Z.; Baertsch, R.; Neeman, E.; Gao, A.C.; Thomas, G.V.; et al. MEK-ERK signaling is a therapeutic target in metastatic castration resistant prostate cancer. Prostate Cancer Prostatic Dis. 2019, 22, 531-538. [CrossRef]

217. Garg, R.; Blando, J.; Perez, C.J.; Wang, H.; Benavides, F.J.; Kazanietz, M.G. Activation of nuclear factor кB (NF-кB) in prostate cancer is mediated by protein kinase C epsilon (PKCepsilon). J. Biol. Chem. 2012, 287, 37570-37582. [CrossRef]

218. Gutierrez-Uzquiza, A.; Lopez-Haber, C.; Jernigan, D.L.; Fatatis, A.; Kazanietz, M.G. PKCe Is an Essential Mediator of Prostate Cancer Bone Metastasis. Mol. Cancer Res. 2015, 13, 1336-1346. [CrossRef] [PubMed]

219. Longoni, N.; Sarti, M.; Albino, D.; Civenni, G.; Malek, A.; Ortelli, E.; Pinton, S.; Mello-Grand, M.; Ostano, P.; D’Ambrosio, G.; et al. ETS transcription factor ESE1/ELF3 orchestrates a positive feedback loop that constitutively activates NF- $\mathrm{kB}$ and drives prostate cancer progression. Cancer Res. 2013, 73, 4533-4547. [CrossRef] [PubMed] 
220. Staal, J.; Beyaert, R. Inflammation and NF-кB Signaling in Prostate Cancer: Mechanisms and Clinical Implications. Cells 2018, 7, 122. [CrossRef]

221. Nunes, J.J.; Pandey, S.K.; Yadav, A.; Goel, S.; Ateeq, B. Targeting NF-kappa B Signaling by Artesunate Restores Sensitivity of Castrate-Resistant Prostate Cancer Cells to Antiandrogens. Neoplasia 2017, 19, 333-345. [CrossRef]

222. Casey, S.C.; Tong, L.; Li, Y.; Do, R.; Walz, S.; Fitzgerald, K.N.; Gouw, A.M.; Baylot, V.; Gütgemann, I.; Eilers, M.; et al. MYC regulates the antitumor immune response through CD47 and PD-L1. Science 2016, 352, 227-231. [CrossRef]

223. Shah, K.V.; Chien, A.J.; Yee, C.; Moon, R.T. CTLA-4 is a direct target of Wnt/beta-catenin signaling and is expressed in human melanoma tumors. J. Investig. Derm. 2008, 128, 2870-2879. [CrossRef]

224. Sidaway, P. Prostate cancer: Wnt signalling induces resistance. Urology 2015, 12, 597. [PubMed]

225. Yokoyama, N.N.; Shao, S.; Hoang, B.H.; Mercola, D.; Zi, X. Wnt signaling in castration-resistant prostate cancer: Implications for therapy. Am. J. Clin. Exp. Urol. 2014, 2, 27-44.

226. Gerstein, A.V.; Almeida, T.A.; Zhao, G.; Chess, E.; Shih, I.; Buhler, K.; Pienta, K.; Rubin, M.A.; Vessella, R.; Papadopoulos, N. APC/CTNNB1 (beta-catenin) pathway alterations in human prostate cancers. Genes Chromosomes Cancer 2002, 34, 9-16. [CrossRef]

227. Beltran, H.; Yelensky, R.; Frampton, G.M.; Park, K.; Downing, S.R.; MacDonald, T.Y.; Jarosz, M.; Lipson, D.; Tagawa, S.T.; Nanus, D.M.; et al. Targeted next-generation sequencing of advanced prostate cancer identifies potential therapeutic targets and disease heterogeneity. Eur. Urol. 2013, 63, 920-926. [CrossRef] [PubMed]

228. Pak, S.; Park, S.; Kim, Y.; Park, J.H.; Park, C.H.; Lee, K.J.; Kim, C.S.; Ahn, H. The small molecule WNT/ $\beta$-catenin inhibitor CWP232291 blocks the growth of castration-resistant prostate cancer by activating the endoplasmic reticulum stress pathway. $J$. Exp. Clin. Cancer Res. 2019, 38, 342. [CrossRef] [PubMed]

229. Zhang, Z.; Cheng, L.; Li, J.; Farah, E.; Atallah, N.M.; Pascuzzi, P.E.; Gupta, S.; Liu, X. Inhibition of the Wnt/ $\beta$-Catenin Pathway Overcomes Resistance to Enzalutamide in Castration-Resistant Prostate Cancer. Cancer Res. 2018, 78, 3147-3162. [CrossRef] [PubMed]

230. Heinlein, C.A.; Chang, C. Androgen receptor in prostate cancer. Endocr. Rev. 2004, 25, 276-308. [CrossRef]

231. Schaufele, F.; Carbonell, X.; Guerbadot, M.; Borngraeber, S.; Chapman, M.S.; Ma, A.A.; Miner, J.N.; Diamond, M.I. The structural basis of androgen receptor activation: Intramolecular and intermolecular amino-carboxy interactions. Proc. Natl. Acad. Sci. USA 2005, 102, 9802-9807. [CrossRef]

232. Van Royen, M.E.; van Cappellen, W.A.; de Vos, C.; Houtsmuller, A.B.; Trapman, J. Stepwise androgen receptor dimerization. J. Cell Sci. 2012, 125, 1970-1979. [CrossRef]

233. Tan, M.H.; Li, J.; Xu, H.E.; Melcher, K.; Yong, E.L. Androgen receptor: Structure, role in prostate cancer and drug discovery. Acta Pharm. Sin. 2015, 36, 3-23. [CrossRef] [PubMed]

234. De Bosscher, K.; Vanden, B.W.; Haegeman, G. Cross-talk between nuclear receptors and nuclear factor kappaB. Oncogene 2006, 25, 6868-6886. [CrossRef]

235. Izumi, K.; Fang, L.Y.; Mizokami, A.; Namiki, M.; Li, L.; Lin, W.J.; Chang, C. Targeting the androgen receptor with siRNA promotes prostate cancer metastasis through enhanced macrophage recruitment via CCL2/CCR2-induced STAT3 activation. EMBO Mol. Med. 2013, 5, 1383-1401. [CrossRef] [PubMed]

236. Henshall, S.M.; Quinn, D.I.; Lee, C.S.; Head, D.R.; Golovsky, D.; Brenner, P.C.; Delprado, W.; Stricker, P.D.; Grygiel, J.J.; Sutherland, R.L. Altered expression of androgen receptor in the malignant epithelium and adjacent stroma is associated with early relapse in prostate cancer. Cancer Res. 2001, 61, 423-427. [PubMed]

237. Leach, D.A.; Buchanan, G. Stromal Androgen Receptor in Prostate Cancer Development and Progression. Cancers 2017, 9 , 10. [CrossRef]

238. Gomella, L.G.; Singh, J.; Lallas, C.; Trabulsi, E.J. Hormone therapy in the management of prostate cancer: Evidence-based approaches. Adv. Urol. 2010, 2, 171-181. [CrossRef] [PubMed]

239. Koh, Y.T.; Gray, A.; Higgins, S.A.; Hubby, B.; Kast, W.M. Androgen ablation augments prostate cancer vaccine immunogenicity only when applied after immunization. Prostate 2009, 69, 571-584. [CrossRef]

240. Young, C.; Horton, R. Putting clinical trials into context. Lancet 2005, 366, 107-108. [CrossRef]

241. Palicelli, A.; Giaccherini, L.; Zanelli, M.; Bonasoni, M.P.; Gelli, M.C.; Bisagni, A.; Zanetti, E.; De Marco, L.; Torricelli, F.; Manzotti, G.; et al. How Can We Treat Vulvar Carcinoma in Pregnancy? A Systematic Review of the Literature. Cancers 2021, 13, 836. [CrossRef]

242. Wing-Cheuk Wong, R.; Palicelli, A.; Hoang, L.; Singh, N. Interpretation of p16, p53 and mismatch repair protein immunohistochemistry in gynaecological neoplasia. Diagn. Histopathol. 2020, 26, 257-277. [CrossRef]

243. Sanguedolce, F.; Calò, B.; Mancini, V.; Zanelli, M.; Palicelli, A.; Zizzo, M.; Ascani, S.; Carrieri, G.; Cormio, L. Non-Muscle Invasive Bladder Cancer with Variant Histology: Biological Features and Clinical Implications. Oncology 2021, 99, 345-358. [CrossRef]

244. Zanelli, M.; Sanguedolce, F.; Zizzo, M.; Palicelli, A.; Bassi, M.C.; Santandrea, G.; Martino, G.; Soriano, A.; Caprera, C.; Corsi, M.; et al. Primary effusion lymphoma occurring in the setting of transplanted patients: A systematic review of a rare, life-threatening post-transplantation occurrence. BMC Cancer 2021, 21, 468. [CrossRef] [PubMed]

245. Sanguedolce, F.; Zanelli, M.; Zizzo, M.; Bisagni, A.; Soriano, A.; Cocco, G.; Palicelli, A.; Santandrea, G.; Caprera, C.; Corsi, M.; et al. Primary Pulmonary B-Cell Lymphoma: A Review and Update. Cancers 2021, 13, 415. [CrossRef] [PubMed] 
246. Bonasoni, M.P.; Palicelli, A.; Dalla Dea, G.; Comitini, G.; Pazzola, G.; Russello, G.; Bertoldi, G.; Bardaro, M.; Zuelli, C.; Carretto, E. Kingella kingae Intrauterine Infection: An Unusual Cause of Chorioamnionitis and Miscarriage in a Patient with Undifferentiated Connective Tissue Disease. Diagnostics 2021, 11, 243. [CrossRef]

247. Bonasoni, M.P.; Palicelli, A.; Dalla Dea, G.; Comitini, G.; Nardini, P.; Vizzini, L.; Russello, G.; Bardaro, M.; Carretto, E. Klebsiella pneumoniae Chorioamnionitis: An Underrecognized Cause of Preterm Premature Rupture of Membranes in the Second Trimester. Microorganisms 2021, 9, 96. [CrossRef]

248. Olivadese, R.; Ramponi, A.; Boldorini, R.; Dalla Dea, G.; Palicelli, A. Mitotically Active Cellular Fibroma of the Ovary Recurring After the Longest Interval of Time (16 yr): A Challenging Case With Systematic Literature Review. Int. J. Gynecol. Pathol. 2021, 40, 441-447. [CrossRef]

249. Zanelli, M.; Ricci, S.; Zizzo, M.; Sanguedolce, F.; De Giorgi, F.; Palicelli, A.; Martino, G.; Ascani, S. Systemic Mastocytosis Associated with "Smoldering" Multiple Myeloma. Diagnostics 2021, 11, 88. [CrossRef]

250. Palicelli, A. What do we know about the cytological features of pure intraductal carcinomas of the salivary glands? Cytopathology 2020, 31, 185-192. [CrossRef]

251. Palicelli, A. Intraductal carcinomas of the salivary glands: Systematic review and classification of 93 published cases. Apmis 2020, 128, 191-200. [CrossRef]

252. Ardighieri, L.; Palicelli, A.; Ferrari, F.; Bugatti, M.; Drera, E.; Sartori, E.; Odicino, F. Endometrial Carcinomas with Intestinal-Type Metaplasia/Differentiation: Does Mismatch Repair System Defects Matter? Case Report and Systematic Review of the Literature. J. Clin. Med. 2020, 9, 2552. [CrossRef] [PubMed]

253. D'Agostino, C.; Surico, D.; Monga, G.; Palicelli, A. Pregnancy-related decidualization of subcutaneous endometriosis occurring in a post-caesarean section scar: Case study and review of the literature. Pathol. Res. Pr. 2019, 215, 828-831. [CrossRef]

254. Palicelli, A.; Barbieri, P.; Mariani, N.; Re, P.; Galla, S.; Sorrentino, R.; Locatelli, F.; Salfi, N.; Valente, G. Unicystic high-grade intraductal carcinoma of the parotid gland: Cytological and histological description with clinic-pathologic review of the literature. Apmis 2018, 126, 771-776. [CrossRef]

255. Palicelli, A.; Neri, P.; Marchioro, G.; De Angelis, P.; Bondonno, G.; Ramponi, A. Paratesticular seminoma: Echographic features and histological diagnosis with review of the literature. Apmis 2018, 126, 267-272. [CrossRef]

256. Disanto, M.G.; Mercalli, F.; Palicelli, A.; Arnulfo, A.; Boldorini, R. A unique case of bilateral ovarian splenosis and review of the literature. Apmis 2017, 125, 844-848. [CrossRef]

257. Palicelli, A.; Disanto, M.G.; Panzarasa, G.; Veggiani, C.; Galizia, G.; Dal Cin, S.; Gruppioni, E.; Boldorini, R. Orbital meningeal melanocytoma: Histological, immunohistochemical and molecular characterization of a case and review of the literature. Pathol. Res. Pr. 2016, 212, 946-953. [CrossRef] [PubMed]

258. Zanelli, M.; Smith, M.; Zizzo, M.; Carloni, A.; Valli, R.; De Marco, L.; Foroni, M.; Palicelli, A.; Martino, G.; Ascani, S. A tricky and rare cause of pulmonary eosinophilia: Myeloid/lymphoid neoplasm with eosinophilia and rearrangement of PDGFRA. BMC Pulm. Med. 2019, 19, 216. [CrossRef]

259. Palicelli, A.; Boldorini, R.; Campisi, P.; Disanto, M.G.; Gatti, L.; Portigliotti, L.; Tosoni, A.; Rivasi, F. Tungiasis in Italy: An imported case of Tunga penetrans and review of the literature. Pathol. Res. Pr. 2016, 212, 475-483. [CrossRef] [PubMed]

260. Ambrosetti, F.; Palicelli, A.; Bulfamante, G.; Rivasi, F. Langer mesomelic dysplasia in early fetuses: Two cases and a literature review. Fetal. Pediatr. Pathol. 2014, 33, 71-83. [CrossRef]

261. Mandato, V.D.; Mastrofilippo, V.; Palicelli, A.; Silvotti, M.; Serra, S.; Giaccherini, L.; Aguzzoli, L. Solitary vulvar metastasis from early-stage endometrial cancer: Case report and literature review. Medicine 2021, 100, e25863. [CrossRef] [PubMed]

262. Ardighieri, L.; Palicelli, A.; Ferrari, F.; Ragnoli, M.; Ghini, I.; Bugatti, M.; Bercich, L.; Sartori, E.; Odicino, F.E. Risk Assessment in Solitary Fibrous Tumor of the Uterine Corpus: Report of a Case and Systematic Review of the Literature. Int. J. Surg. Pathol. 2021, 28, 10668969211025759. [CrossRef] [PubMed]

263. Zanelli, M.; Pizzi, M.; Sanguedolce, F.; Zizzo, M.; Palicelli, A.; Soriano, A.; Bisagni, A.; Martino, G.; Caprera, C.; Moretti, M.; et al. Gastrointestinal Manifestations in Systemic Mastocytosis: The Need of a Multidisciplinary Approach. Cancers 2021, $13,3316$. [CrossRef] [PubMed]

264. Donegani, E.; Ambassa, J.C.; Mvondo, C.; Giamberti, A.; Ramponi, A.; Palicelli, A.; Chelo, D. Linfoma di Burkitt cardiaco primitivo in un giovane ragazzo africano [Primary cardiac Burkitt lymphoma in an African child]. Giornale Italiano Cardiologia 2013, 14, 481-484.

265. Zanelli, M.; Ragazzi, M.; Marchetti, G.; Bisagni, A.; Principi, M.; Fanni, D.; Froio, E.; Serra, S.; Zanetti, E.; De Marco, L.; et al. Primary histiocytic sarcoma presenting as diffuse leptomeningeal disease: Case description and review of the literature. Neuropathology 2017, 37, 517-525. [CrossRef]

266. Bonasoni, M.P.; Comitini, G.; Barbieri, V.; Palicelli, A.; Salfi, N.; Pilu, G. Fetal Presentation of Mediastinal Immature Teratoma: Ultrasound, Autopsy and Cytogenetic Findings. Diagnostics 2021, 11, 1543. [CrossRef]

267. Zanelli, M.; Sanguedolce, F.; Palicelli, A.; Zizzo, M.; Martino, G.; Caprera, C.; Fragliasso, V.; Soriano, A.; Valle, L.; Ricci, S.; et al. EBV-Driven Lymphoproliferative Disorders and Lymphomas of the Gastrointestinal Tract: A Spectrum of Entities with a Common Denominator (Part 1). Cancers 2021, 13, 4578. [CrossRef] [PubMed]

268. Zanelli, M.; Sanguedolce, F.; Palicelli, A.; Zizzo, M.; Martino, G.; Caprera, C.; Fragliasso, V.; Soriano, A.; Valle, L.; Ricci, S.; et al. EBV-Driven Lymphoproliferative Disorders and Lymphomas of the Gastrointestinal Tract: A Spectrum of Entities with a Common Denominator (Part 2). Cancers 2021, 13, 4527. [CrossRef] 
269. Sanguedolce, F.; Zanelli, M.; Zizzo, M.; Martino, G.; Rossi, C.; Parente, P.; Ascani, S. Clinical, pathological and molecular features of plasmablastic lymphoma arising in the gastrointestinal tract: A review and reappraisal. Pathol. Res. Pract. 2020, $216,152973$. [CrossRef]

270. Zanelli, M.; Zizzo, M.; Montanaro, M.; Gomes, V.; Martino, G.; De Marco, L.; Fraternali, O.G.; Martelli, M.P.; Ascani, S. Fibrinassociated large B-cell lymphoma: First case report within a cerebral artery aneurysm and literature review. BMC Cancer 2019, 19, 916. [CrossRef] [PubMed]

271. Zanelli, M.; Zizzo, M.; Bisagni, A.; Froio, E.; De Marco, L.; Valli, R.; Filosa, A.; Luminari, S.; Martino, G.; Massaro, F.; et al. Germinotropic lymphoproliferative disorder: A systematic review. Ann. Hematol. 2020, 99, 2243-2253. [CrossRef]

272. Sanguedolce, F.; Zanelli, M.; Zizzo, M.; Luminari, S.; Martino, G.; Soriano, A.; Ricci, L.; Caprera, C.; Ascani, S. Indolent T-cell lymphoproliferative disorders of the gastrointestinal tract (iTLPD-GI): A review. Cancers 2021, 13, 2790. [CrossRef] [PubMed]

273. Palicelli, A.; Bonacini, M.; Croci, S.; Magi-Galluzzi, C.; Cañete-Portillo, S.; Chaux, A.; Bisagni, A.; Zanetti, E.; De Biase, D.; Melli, B.; et al. What do we have to know about PD-L1 expression in prostate cancer? A systematic literature review. Part 1: Focus on immunohistochemical results with discussion of pre-analytical and interpretation variables. Cells 2021, 10, 3166. [CrossRef]

274. Palicelli, A.; Bonacini, M.; Croci, S.; Magi-Galluzzi, C.; Cañete-Portillo, S.; Chaux, A.; Bisagni, A.; Zanetti, E.; De Biase, D.; Melli, B.; et al. What do we have to know about PD-L1 expression in prostate cancer? A systematic literature review. Part 2: Clinic-pathologic correlations. Cells 2021, 10, 3165. [CrossRef]

275. Palicelli, A.; Croci, S.; Bisagni, A.; Zanetti, E.; De Biase, D.; Melli, B.; Sanguedolce, F.; Ragazzi, M.; Zanelli, M.; Chaux, A.; et al. What do we have to know about PD-L1 expression in prostate cancer? A systematic literature review. Part 4: Experimental treatments in pre-clinical studies (cell lines and mouse models). Int. J. Mol. Sci. 2021, 22, 12297. [CrossRef]

276. Palicelli, A.; Croci, S.; Bisagni, A.; Zanetti, E.; De Biase, D.; Melli, B.; Sanguedolce, F.; Ragazzi, M.; Zanelli, M.; Chaux, A.; et al. What do we have to know about PD-L1 expression in prostate cancer? A systematic literature review. Part 5: Epigenetic regulation of PD-L1. Int. J. Mol. Sci. 2021, 22, 12314. [CrossRef] 